\title{
TECNOLOGIA DE PRODUÇÃO DE MAXIXE PAULISTA (Cucumis anguria L.)
}

\section{VALÉRIA APARECIDA MODOLO}

Tese apresentada à Escola Superior de Agricultura "Luiz de Queiroz" Universidade de São Paulo, para a obtenção do Título de Doutor em Agronomia, Área de Concentração: Fitotecnia.

PIRACICABA

Estado de São Paulo - Brasil

Julho - 2002 


\section{TECNOLOGIA DE PRODUÇÃO DE MAXIXE PAULISTA (Cucumis anguria $\mathrm{L}$.}

\section{VALÉRIA APARECIDA MODOLO}

Engenheira Agrônoma

Orientador: Prof. Dr. CYRO PAULINO DA COSTA

Tese apresentada à Escola Superior de Agricultura "Luiz de Queiroz" Universidade de São Paulo, para obtenção do Título de

Doutor em Agronomia, Área de Concentração: Fitotecnia.

PIRACICABA

Estado de São Paulo - Brasil

Julho - 2002 
Dados Internacionais de Catalogação na Publicação (CIP)

DIVISÃO DE BIBLIOTECA E DOCUMENTAÇÃO - ESALQ/USP

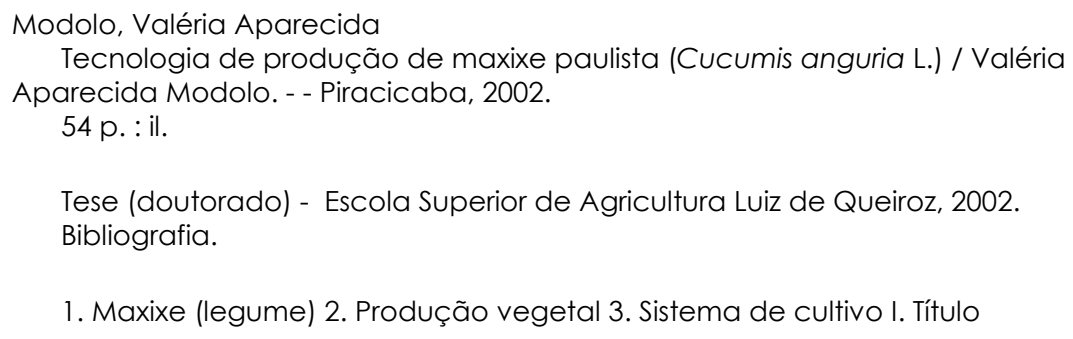

"Permitida a cópia total ou parcial deste documento, desde que citada a fonte - O autor" 
In plantis semper parens juventus et in plantis resurgo

"Nas plantas a juventude sempre reaparece

e com elas rejuvenesce aquele que as ama"

\section{PROVÉRBIO ROMANO}


Aos meus queridos pais Narcizo e Yvonne por todo amor, confiança e compreensão dedicados em todos os momentos.

Aos meus irmãos Júnior e Bel, e queridos sobrinhos Thiago, Matheus, Victória e Gabriel, pela demonstração de carinho e presença constante.

\section{Ofereço}

Ao meu marido Juan, por tanto amor, apoio e compreensão.

\section{Dedico}




\section{AGRADECIMENTOS}

À DEUS, por sempre indicar os melhores caminhos na minha vida;

Ao Prof. Dr. Cyro Paulino da Costa, pela orientação segura e eficiente, durante todos os momentos necessários e pela amizade despendida;

A Profa. Dra. Rumy Goto, pelas valiosas contribuições e sugestões;

Aos Profs. Drs. Keigo Minami, João Tessarioli Neto e Paulo César Tavares de Melo pelos ensinamentos transmitidos com as disciplinas ministradas durante o curso;

Aos Profs. Drs. Luiz Carlos Marchini e Jorge Rezende pelos prestativos ensinamentos e principalmente pela colaboração nos experimentos;

A Soraia França, por tão sincera amizade, paciência e valiosas contribuições na finalização deste trabalho;

Aos colegas do curso, Fernando Sala, Léa Araújo de Carvalho, Saly Blat, Tamara M. Gomes e Thaysa Guimarães Fonseca, pelo convívio e ajuda prestada durante o desenvolvimento da pesquisa;

Aos funcionários do Campo Experimental do Departamento de Produção Vegetal, pela atenção especial e colaboração na execução desta pesquisa;

Ao Departamento de Produção Vegetal, professores e funcionários, especialmente a Bete, Célia, Helena e Luciane, pela atenção, carinho e amizade.

Aos funcionários da Seção de Pós-Graduação e da Biblioteca, pela gentileza e simpatia no atendimento prestado;

À FAPESP, pelo apoio financeiro. 


\section{SUMÁRIO}

Página

LISTA DE FIGURAS.................................................................................... viii

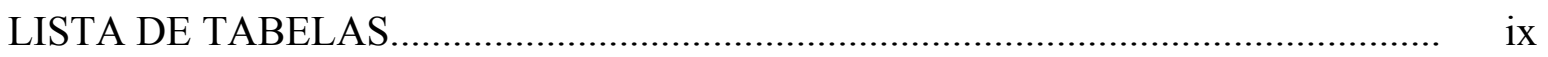

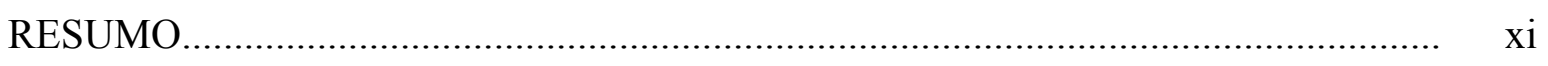

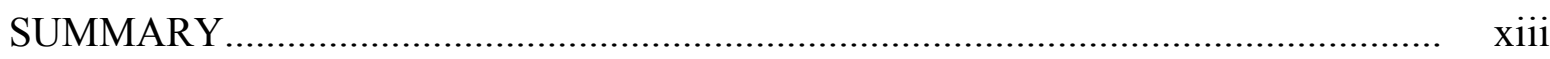

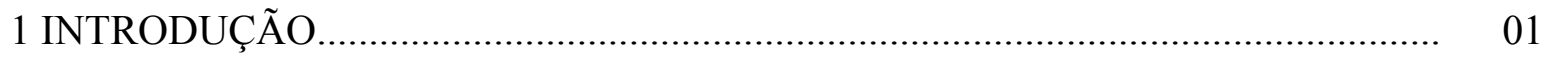

2 REVISÃO DE LITERATURA........................................................................... 03

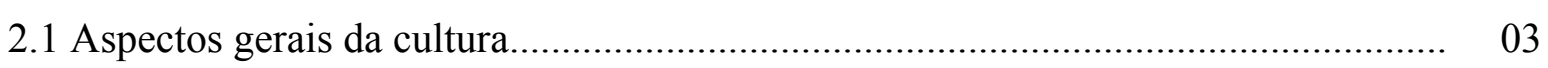

2.1.1 Gênero Cucumis................................................................................... 03

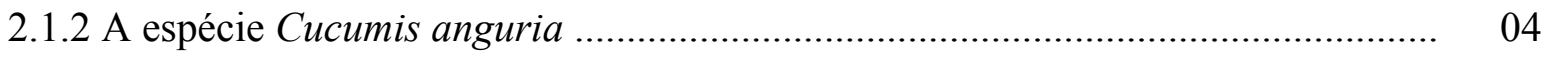

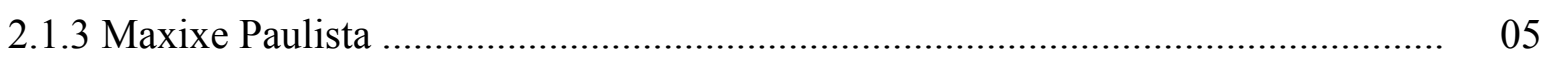

2.2 Manejo e tecnologia de produção de Cucumis...................................................... 08

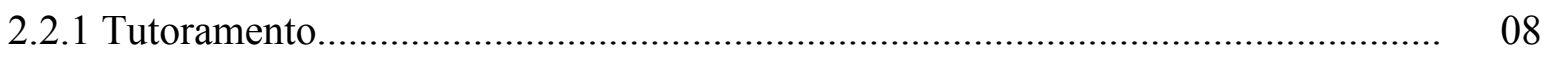

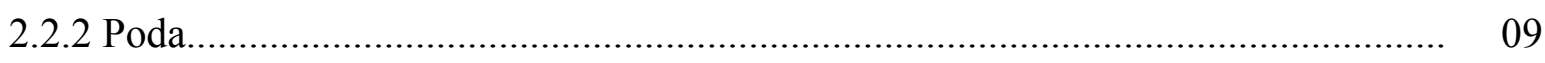

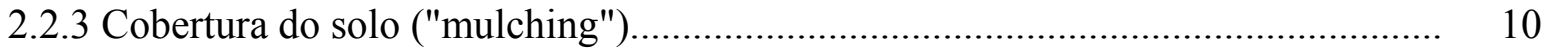

2.2.4 Produção em ambiente protegido e cultivo em substrato................................... 11

3 CULTIVO DE MAXIXE PAULISTA EM CANTEIROS COM COBERTURA DE

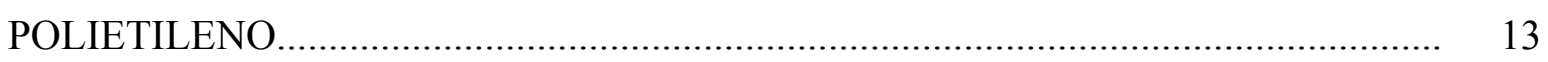

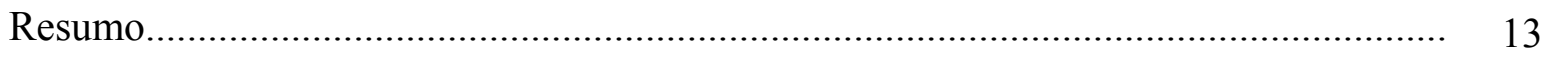

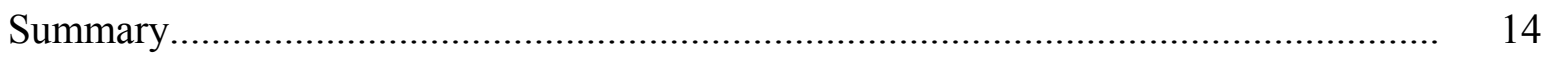

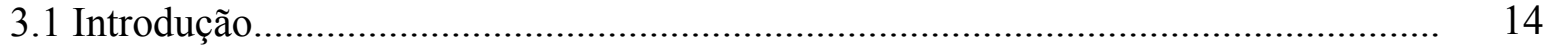


Página

3.2 Material e Métodos...................................................................................... 17

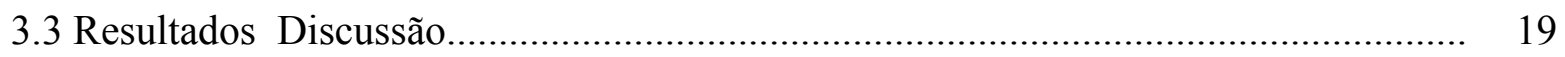

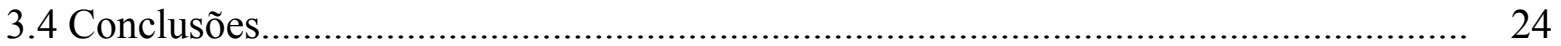

4 CONDUÇÃO DE MAXIXE PAULISTA EM AMBIENTE PROTEGIDO................. 25

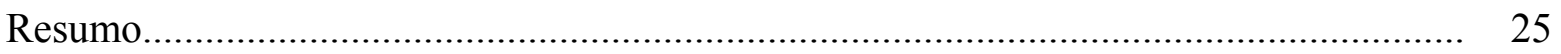

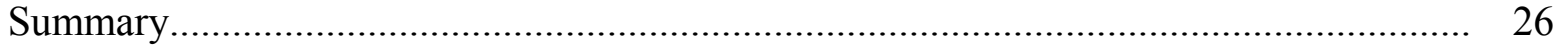

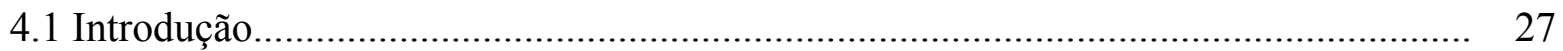

4.2 Material e Métodos............................................................................................. 29

4.3 Resultados e Discussão............................................................................ 31

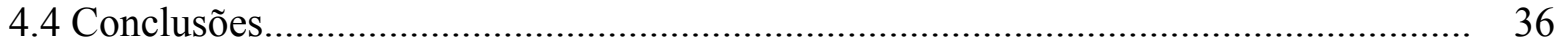

5 CONDUÇÃO DE HÍBRIDOS DE MAXIXE PAULISTA EM REDE AGRÍCOLA.... 37

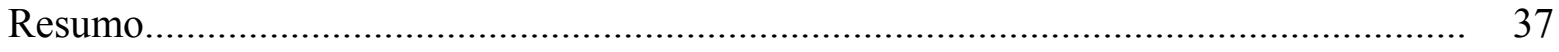

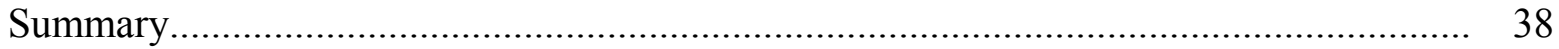

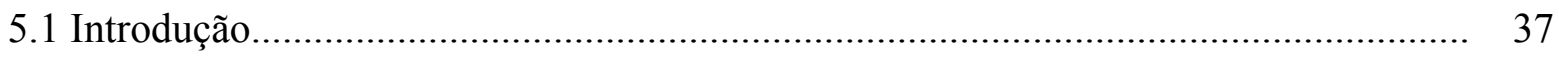

5.2 Material e Métodos....................................................................................... 40

5.3 Resultados e Discussão...................................................................................... 41

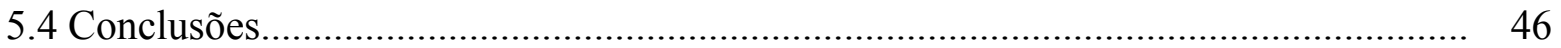

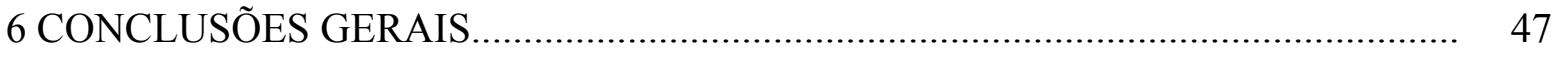

REFERÊNCIAS BIBLIOGRÁFICAS..................................................................... 48 


\section{LISTA DE FIGURAS}

Página

1 Origem e genealogia das linhagens elites de Maxixe Paulista................................ 7

2 Maxixe Comum e linhagens de Maxixe Paulista................................................... 8

3 Massa total $(\mathrm{kg})$ de frutos/parcela de 8 plantas das linhagens L1, L2 e L60 de Maxixe Paulista e do tipo Comum (A), durante as 10 etapas de colheita.

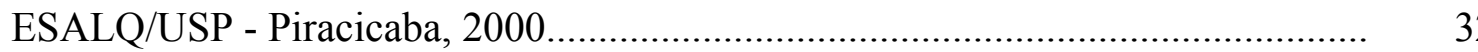

4 Número total de frutos/parcela de 8 plantas das linhagens L1, L2 e L60 de Maxixe Paulista e do tipo Comum (A), durante as 10 etapas de colheita. ESALQ/USP -

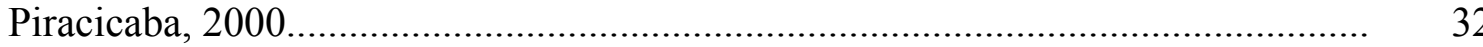

5 Predominância da brotação lateral basal da planta de maxixe.................................. 34

6 Número total de frutos/parcela de 7 plantas das linhagens L1, L2, L4 e L60 e híbridos H3, H5, H6, H61, H62, H64 de Maxixe Paulista, durante as 6 etapas de

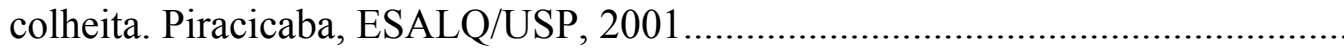

7 Massa total $(\mathrm{kg})$ de frutos/parcela e 7 plantas das linhagens L1, L2, L4 e L60 e híbridos H3, H5, H6, H61, H62, H64 de Maxixe Paulista, durante as 6 etapas de

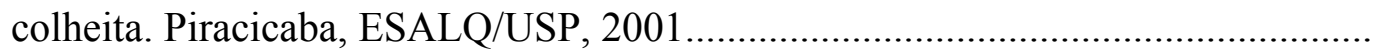




\section{LISTA DE TABELAS}

Página

1 Comparação da produtividade em kg/1.000 plantas entre cultivo em ambiente

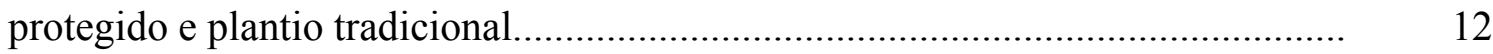

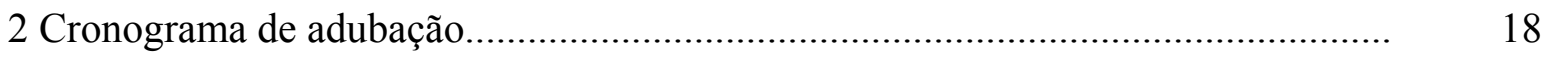

3 Massa de frutos/planta, em kg, de linhagens de Maxixe Paulista L1, L2, L3, L4, L5, L6, L8, L42, L55 e L60 e do tipo Comum (A), nas seis etapas iniciais de

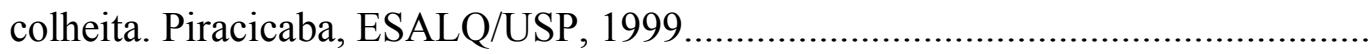

4 Massa de frutos/planta, em kg, de linhagens de Maxixe Paulista L1, L2, L3, L4, L5, L6, L8, L42, L55 e L60) e do tipo Comum (A), nas seis etapas finais de colheita. Piracicaba, ESALQ/USP, 1999

5 Número de frutos/planta de linhagens de Maxixe Paulista L1, L2, L3, L4, L5, L6, L8, L42, L55 e L60 e do tipo Comum (A), nas seis etapas iniciais de colheita. Piracicaba, ESALQ/USP, 1999

6 Número de frutos/planta de linhagens de Maxixe Paulista L1, L2, L3, L4, L5, L6, L8, L42, L55 e L60 e do tipo Comum (A), nas seis etapas finais de colheita. Piracicaba, ESALQ/USP, 1999.

7 Número total (NTF), peso total (PTF) e peso médio (PM) de frutos/parcela de 6 plantas, de Maxixe Paulista (L1; L2; L3; L4; L5; L6; L8; L42; L55 e L60) e do tipo Comum (A), após 12 colheitas. Piracicaba, ESALQ/USP, 1999. 
Página

8 Cronograma de adubação............................................................................. 30

9 Número total (NTF), massa total (MTF) e massa média (MM) de frutos/parcela de 8 plantas e produtividade estimada (PE), das linhagens de Maxixe Paulista (L1, L2, L60) e do tipo Comum (A), após 10 etapas de colheitas. ESALQ/USP Piracicaba, 2000.

10 Número total (NTF), massa total (MTF) e massa média (MM) de frutos/parcela de 7 plantas, de linhagens L1, L2, L4 e L60 e híbridos H3, H5, H6, H61, H62, H64 de Maxixe Paulista, após 6 colheitas. Piracicaba, ESALQ/USP, 2001

11 Comprimento (C), largura (L), espessura de polpa (EP) e relação comprimento/largura (C/L) de linhagens L1, L2, L4 e L60 e híbridos H3, H5, H6, H61, H62, H64 de Maxixe Paulista. Piracicaba, ESALQ/USP, 2001............. 


\title{
TECNOLOGIA DE PRODUÇÃO DE MAXIXE PAULISTA (Cucumis anguria L.)
}

\author{
Autora: VALÉRIA APARECIDA MODOLO \\ Orientador: Prof. Dr. CYRO PAULINO DA COSTA
}

\section{RESUMO}

Maxixe Paulista é um novo tipo de maxixe obtido a partir do cruzamento de Cucumis anguria x Cucumis longipes. Após ciclos de seleção massal intercalados a ciclos de endogamia, foram obtidas linhagens que diferem do tipo comum pelas suas características de ausência de espiculosidade, tamanho de fruto e formato de folha não lobulada semelhante ao pepino. Em três ensaios de campo, linhagens e híbridos de Maxixe Paulista foram avaliados quanto ao comportamento e produção de frutos em três sistemas de cultivo: a) com cobertura de polietileno e fertirrigação; b) cultivados em vasos com substrato, com tutoramento e podas e em ambiente protegido; c) no sistema de cultivo tutorado em rede agrícola. No primeiro ensaio, foram avaliadas dez linhagens de Maxixe Paulista e uma cultivar do Maxixe Comum. As linhagens de Maxixe Paulista apresentaram um peso médio de fruto de 66 a 91\% maior que o tipo Comum. A produção em peso total de frutos não diferiu entre os dois tipos de maxixe. O cultivo em canteiros com cobertura de polietileno e fertirrigação por gotejamento proporcionou uma produtividade estimada de 51,89t.ha ${ }^{-1}$. No segundo ensaio, três linhagens do Maxixe Paulista e o tipo Comum foram cultivados em vasos com substrato, em ambiente protegido, com tutoramento e podas. As linhagens de Maxixe Paulista apresentaram um peso médio de fruto de 62 a $84 \%$ maior que o tipo Comum. A 
linhagem 2 foi tão produtiva, em termo de peso total, quanto o tipo Comum porém seu peso médio de fruto foi $75 \%$ maior. A planta de maxixe mostrou ser inadequada para condução no protocolo de tutoramento e podas da cultura do pepino. No terceiro ensaio, foram avaliadas quatro linhagens e seis híbridos simples, quanto ao comportamento e produção de frutos no sistema de cultivo tutorado em rede agrícola. A produção e a qualidade dos frutos dos híbridos foi equivalente a das linhagens. A rede agrícola se mostrou adequada para o cultivo de Maxixe Paulista na forma tutorada. A concentração da frutificação ocorreu nas hastes secundárias e terciárias, cujas gavinhas mantiveram as plantas presas à rede. Esta técnica de condução facilitou a colheita e incrementou a qualidade dos frutos. 


\title{
PAULISTA GHERKIN TECHNOLOGIC PRODUCTION (Cucumis anguria L.)
}

\author{
Author: VALÉRIA APARECIDA MODOLO \\ Adviser: Prof. Dr. CYRO PAULINO DA COSTA
}

\section{SUMMARY}

Paulista Gherkin is a new gherkin type derived from Cucumis anguria x Cucumis longipes. After mass selection cycles intercalated with inbreeding cycles, lines were obtained that differ from the common types by their greater fruit size, spine abscence and non-lobular shaped leaves, similar to cucumber ones. In three experiments, Paulista gherkin lines and hybrids were evaluated for their yield and fruit production in three production systems: a) under polyethylene mulching and fertigation crop system; b) trellised and pruned plants grown in pots with substrate under high plastic tunnel; c) under the trellised net crop system. In the first experiment, ten lines of Paulista Gherkin and one type of Common Gherkin were evaluated. Paulista Gherkin fruits were, in average, 66 to $91 \%$ heavier than the Common Gherkin ones. Total fruit weight, of two gherkin types did not differ. Polyethylene-covered bed and drip fertigation use promoted an estimate yield of 51,89 t.ha ${ }^{-1}$. In the second experiment, three Paulista Gherkin lines and Common Gherkin were cultivated in pots with substrate, under high plastic tunnel and they were trellised and pruned. Paulista Gherkin fruits were, in average, 62 to $84 \%$ heavier than the Common Gherkin ones. Paulista Gherkin line number 2 was productive as the Common type, considering the total fruits weight. However, its average fruit weight was $75 \%$ higher. Gherkin plants showed to be inadequate for to be conducted as 
suggested for the greenhouse cucumber crop protocol. In the third experiment, four lines and six single hybrids performance were evaluated for their yield and fruit production under trellised net crop system. Hybrids and lines were similar for yield and fruit quality. The trellised net crop system showed to be suitable to support Paulista Gherkin plants. Fruit concentration occurred in the secondary and tertiary lateral branch and plants was hold by tendrils on the net. Trellised gherkin in net mate harvest easier and enhance fruit quality. 


\section{INTRODUÇÃO}

O maxixeiro é uma planta de origem africana, cultivada de maneira subespontânea principalmente nas regiões norte e nordeste do Brasil. Nestas regiões, esta hortaliça participa da culinária tradicional sendo consumida na forma da "maxixada", onde o fruto maduro é cozido com outros ingredientes.

Existe uma grande demanda de consumo desta olerácea devido à intensa migração de nordestinos que ocorre por todo o país. Além disso, a tendência de mercado faz com que aumente a busca por produtos alternativos em relação aos padrões tradicionais.

As populações brasileiras de maxixe caracterizam-se pela produção de frutos sem sabor amargo e com grandes variações quanto à espiculosidade e ao tamanho do fruto. $\mathrm{O}$ maxixe comum é uma espécie na qual o processo de melhoramento tem sido mínimo.

Maxixe Paulista é um novo tipo de maxixe derivado originalmente do cruzamento de Cucumis anguria x Cucumis longipes, com características distintas de fruto e folhas. Esta cultura apresenta alto potencial para o consumo na forma de salada ou no segmento de consumo em conserva, na forma de picles. Pode ser consumida ainda imatura, como uma alternativa da cultura de pepino, ou cozida, como alternativa de abobrinha. Porém, para promover o cultivo, é necessário modernizar sua tecnologia de produção, pois o cultivo do maxixe comum é feito de maneira obsoleta.

Nas culturas de pepino e melão, as duas espécies expoentes do gênero Cucumis, a demanda da melhor qualidade incentivou o uso de práticas altamente tecnificadas, com intenso manejo das plantas. Sendo o maxixe considerado uma cultura-irmã do pepino, cujos hábitos vegetativos e reprodutivos são similares, postula-se que o modelo de 
cultivo, práticas culturais e manejo desta cultura poderiam ser adotados para o Maxixe Paulista.

Muitas são as técnica utilizadas na tecnologia de produção de pepino. Dentre elas, pode-se destacar o cultivo utilizando cobertura de polietileno; condução vertical, com manejo de podas e tutoramento e cultivo em ambiente protegido. Para a introdução destas técnicas no cultivo de Maxixe Paulista, seria imprescindível verificar o comportamento de linhagens e híbridos e sua adequação nos diferentes tipos de manejo.

O objetivo desta pesquisa foi verificar o comportamento e avaliar a produção de frutos de Maxixe Paulista em três sistemas de produção: a) em canteiros, no sistema rasteiro, utilizando cobertura de polietileno e fertirrigação; b) em ambiente protegido, com tutoramento e podas, sendo as plantas cultivadas em substrato; c) em campo, no sistema de cultivo tutorado em rede agrícola e sem podas. 


\section{REVISÃO DE LITERATURA}

\subsection{Aspectos gerais da cultura}

\subsubsection{Gênero Cucumis}

$\mathrm{Na}$ família Cucurbitaceae, há cerca de 30 espécies pertencentes a 9 gêneros, muitas das quais são utilizadas como alimento (Esquinas-Alcazar \& Gulick, 1983). Dentre os gêneros, destacam-se Cucurbita e Cucumis, ambos polimórficos e amplamente cultivados nos países desenvolvidos.

Quanto à origem, as espécies do gênero Cucumis provêm de duas áreas geográficas distintas: uma situa-se ao leste da África, Península Arábica e leste do Mediterrâneo sendo denominadas de Grupo Africano e a outra situa-se na Índia, ao sul e leste do Himalaia, que abrange as espécies do grupo Asiático. Segundo Leppik (1966), o centro de origem primário de Cucumis situa-se na área com maior concentração das espécies do Grupo Africano. A partir do centro de origem primário das savanas africanas, as espécies selvagens foram disseminadas em muitas direções, onde foram domesticadas. Atualmente, apenas três espécies do gênero Cucumis são cultivadas em grande escala. O pepino (Cucumis sativus L.) e o melão (Cucumis melo L.) apresentam grande valor comercial sendo ambos cosmopolitas. Já o maxixe (Cucumis anguria) é utilizado como alimento em menor escala em algumas regiões do Brasil, no oeste da Índia e no Caribe e (Baird \&Thieret, 1988; Robinson \& Decker-Walters, 1997).

As espécies selvagens de Cucumis caracterizam-se pela produção de frutos amargos, com ampla diversidade de tamanho, cor e espiculosidade. A principal característica agronômica desfavorável das espécies selvagens é a presença de 
cucurbitacina, composto terpenóide que confere sabor amargo aos frutos e em partes vegetativas. O sabor amargo dos frutos constitui um mecanismo de sobrevivência nas savanas africanas, contra animais herbívoros. No entanto, estas espécies selvagens representam um vasto potencial de recursos genéticos a serem utilizados no melhoramento de espécies cultivadas de Cucumis. A hibridação interespecífica entre espécies de Cucumis é utilizada para incorporação de características de resistência a doenças e pragas presentes no material selvagem (Paterniani, 1988).

\subsubsection{A espécie Cucumis anguria $\mathrm{L}$.}

Originalmente foi considerado nativo das Américas, porém, o maxixe teve sua origem na África (Meeuse, 1958), sendo considerado um mutante não-amargo da espécie selvagem africana Cucumis longipes Hook.

No Brasil, foi provavelmente introduzido há cerca de 300 anos, por ocasião do tráfico de escravos africanos (Robinson \& Decker-Walters, 1997). Sendo assim, a maior área de produção desta olerácea ocorre nas regiões brasileiras de forte influência da cultura africana, como o norte, nordeste e sudeste do país. Para os nordestinos, o maxixe constitui-se numa das mais populares hortaliças juntamente com a batata-doce, o inhame, o quiabo e a abóbora, fazendo parte da sua tradição culinária. O consumo ocorre na forma de "maxixada", que consiste no uso de frutos parcialmente imaturos cozidos com outros ingredientes (Yokoyama \& Silva Júnior, 1988). Embora não seja habitual, esta hortaliça também pode ser consumida in natura na forma de salada e sua maior potencialidade seria para o segmento de consumo em conserva na forma de picles (Koch \& Costa, 1991; Robinson \& Decker-Walters, 1997).

A planta de maxixe é monóica, anual como o pepino, com hábito de crescimento indeterminado e prostrado. Com relação ao aspecto vegetativo, esta espécie apresenta folhas lobuladas, em contraste com as folhas não lobuladas típicas de pepino e melão. Os frutos apresentam grande variabilidade quanto ao formato, presença e ausência de espículos e sabor amargo (Lower \& Edwards, 1986; Melo \& Trani, 1998). É uma espécie de clima quente, adaptada à temperatura e pluviosidade elevadas. 
O cultivo do maxixe é predominantemente subespontâneo, consorciado com cereais ou como cultura de subsistência (Paiva, 1984; Queiroz, 1993). Quando submetido ao cultivo convencional, existem variações quanto à produtividade dependendo da época e do local de cultivo. Na Amazônia, no período de menor pluviosidade, as cultivares maxixe liso e maxixe com espículos produziram 110 e 165 frutos/cova, com massa média de 37 e 38g/fruto, respectivamente (Pimentel, 1985). No Maranhão, a produtividade média é de $16 \mathrm{t} \mathrm{ha}^{-1}$, porém, no período chuvoso, reduz para aproximadamente 8-10 t.ha ${ }^{-1}$ (Martins, 1986). Em São Paulo, a produtividade é de 12 t.ha ${ }^{-1}$ sendo cultivado preferencialmente de setembro a fevereiro (Melo \& Trani, 1998). Filgueira (2000), considerando de uma maneira geral, relata que a produtividade da cultura se situa em torno de 4 - 5 t.ha ${ }^{-1}$.

\subsubsection{Maxixe Paulista}

As populações brasileiras de maxixe comum se caracterizam pela produção de frutos sem sabor amargo, mas com grandes variações quanto à espiculosidade e ao tamanho do fruto (Paiva, 1994). Queiroz (1993), verificando o potencial do germoplasma do nordeste brasileiro, verificou três tipos bem definidos de frutos de maxixe: lisos, com espículos grossos e esparsos e com espículos finos e muito densos. No entanto, de acordo com Yokoyama (1987), a base genética do germoplasma nacional é bastante restrita sendo sugerido hibridação interespecíficas para ampliá-la usando espécies selvagens compatíveis do mesmo gênero.

Koch \& Costa (1991), a partir de populações parentais da coleção de introduções e germoplasma de Cucumis da ESALQ/USP, realizaram o cruzamento interespecífico entre Cucumis longipes com cultivares de Cucumis anguria. A partir destes resultados foi possível determinar a herança dos caracteres formato da folha, sabor, massa e espiculosidade, facilitando posteriormente a seleção de recombinantes que associem características agronomicamente desejáveis. Estes autores observaram que a herança de formato de folha em maxixe é devido a um gene com dominância incompleta. O sabor obedece à herança simples, sendo que amargo é dominante em relação ao sabor nãoamargo. A espiculosidade é um caráter controlado por dois pares de genes dominantes 
que resultam em frutos com alta espiculosidade, enquanto que frutos lisos, sem espiculosidade, são duplamente recessivos. O caráter massa de fruto é quantitativo e de herança aditiva, o que indica a possibilidade de rápido progresso no melhoramento do maxixe para este caráter de alto valor oleráceo.

Posteriormente, a partir da população F2 obtida por Koch \& Costa (1991), Costa ${ }^{1}$ obteve, após alguns ciclos de seleção massal intercalados a gerações de endogamia, várias dezenas de linhagens elites de maxixe que diferem do tipo comum pela ausência de espiculosidade, maior tamanho de fruto e formato de folha não lobulada semelhante ao pepino (Figura 1). Estas linhagens elites foram avaliadas quanto à uniformidade e características de fruto por Modolo et al. (1999) dando origem a um novo tipo de maxixe que, por apresentar características totalmente distintas do maxixe tradicional, foi denominado de Maxixe Paulista (Figura 2).

Como já foi mencionado, o maxixe comum é raramente submetido ao cultivo convencional e, na maioria das vezes, é coletado a partir de populações subespontâneas em roçados ou em plantios de subsistência. Porém, a promoção e a difusão de um novo produto, com características agronômicas melhoradas demanda modernização de sua tecnologia de produção.

\footnotetext{
${ }^{1}$ COSTA, C.P Comunicação pessoal, 1998.
} 


\section{Cucumis anguria $\quad \mathbf{X} \quad$ Cucumis longipes}

M1

F2 Seleção de frutos não amargos e sem espiculosidade. *

M2

F3 Seleção de folha não lobulada.

M3

F4 Seleção para maior tamanho de fruto.

M4

F5 Autofecundação e seleção de plantas com frutos de massa superior a 90g, não amargos e sem espiculosidade.

$\downarrow$

M5 S1 F6 Avaliação das progênies S1 e seleção para com massa de fruto maduro acima de $90 \mathrm{~g}$

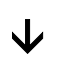

M6 S2 $\quad$ F7 Avaliação e seleção de linhagens S2

M1 - M5 = Ciclos de seleção massal

$\mathrm{S} 1$ - S2 = Gerações de endogamia

* Koch \& Costa (1991)

Figura 1 - Origem e genealogia das linhagens elites de Maxixe Paulista 


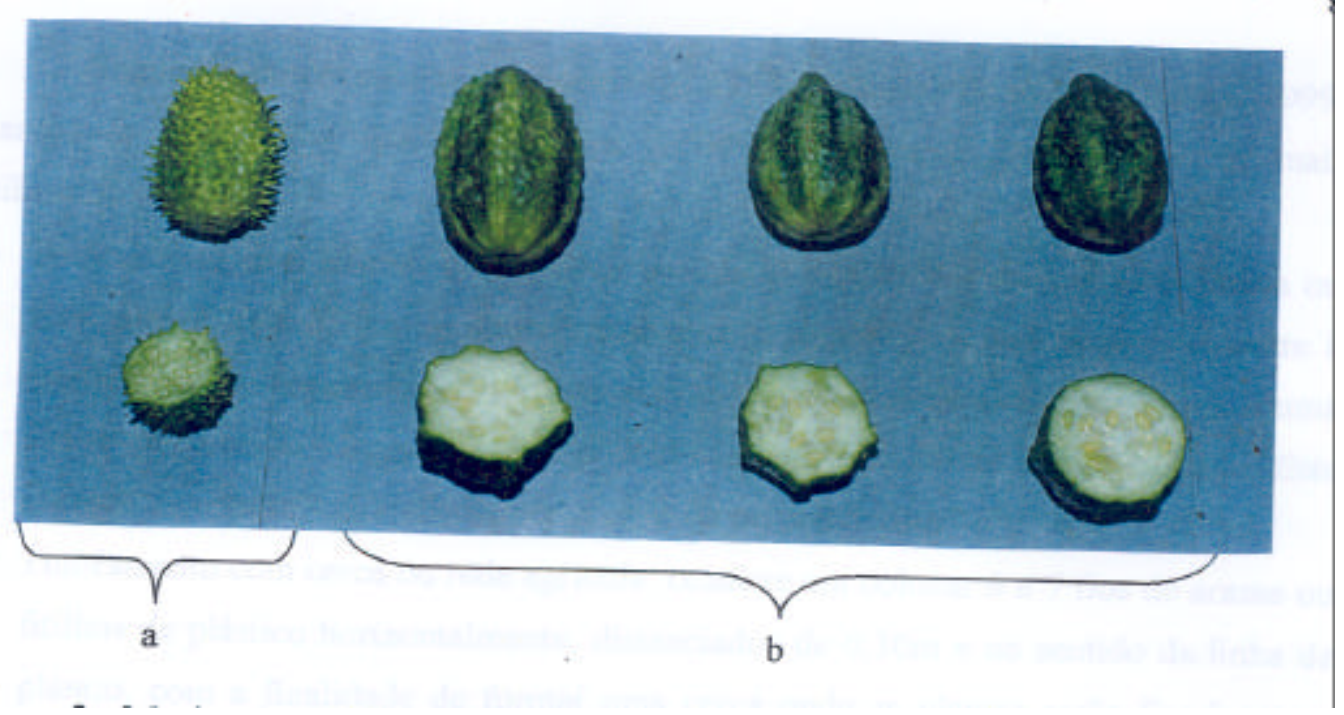

Figura 2 - Maxixe Comum (a) e linhagens de Maxixe Paulista (b).

\subsection{Manejo e tecnologia de produção de Cucumis}

Nas culturas de pepino e melão, as duas espécies importantes do gênero Cucumis, a demanda de produtos com melhor qualidade incentivou o desenvolvimento de cultivos altamente tecnificados, com intenso manejo das plantas. Sendo o maxixe considerado uma cultura-irmã do pepino, cujos hábitos vegetativos e reprodutivos se assemelham, para desenvolver sua tecnologia de produção, o modelo de cultivo, práticas culturais e manejo desta cultura poderiam ser adotados. Dentre estas práticas, algumas serão elucidadas com detalhes a seguir.

\subsubsection{Tutoramento}

O tutoramento consiste em colocar um suporte ou tutor que tem por função auxiliar a condução vertical das plantas. Sua utilização promove melhor aproveitamento do espaço ocupado pelas plantas, obtenção de frutos de qualidade superior, além de diminuir a incidência de doenças pela ventilação mais eficiente entre plantas. Na cultura do pepino, esta prática melhora o aproveitamento da energia solar, uma vez que a planta recebe luz por todos os lados, aumentando de 3 a 5 vezes a produção quando a comparamos ao cultivo rasteiro (Alvarenga, 1982; Illescas \& Vesperinas, 1989). 
Segundo vários autores (Sonnenberg, 1985; Brandão Filho e Callegari, 1999; Carrijo \& Makishima, 2000; Filgueira, 2000), os sistemas de tutoramento mais utilizados são:

a) Tutoramento com estacas ou varas de bambu: Consiste em colocar uma estaca ou vara com 2,20 a 2,50m de altura junto a cada planta, para nela amarrar a haste à medida que ela for crescendo. As estacas de duas fileiras paralelas cruzam-se a uma altura de cerca de 1,80m do solo, apoiando-se sobre um fio de arame esticado. Este sistema é também chamado de cerca cruzada ou cultivo em "V";

b) Tutoramento com cerca ou rede agrícola: consiste em colocar 6 a 7 fios de arame ou fitilhos de plástico horizontalmente, distanciados de $0,30 \mathrm{~m}$ e no sentido da linha de plantio, com a finalidade de formar uma cerca onde as plantas serão fixadas com ajuda de suas gavinhas. Atualmente, existem no mercado redes agrícola, com malhas de tamanho definido, que são usadas da mesma forma que as cercas;

c) Tutoramento com fitilho: consiste em colocar um suporte rígido ou arame número 14, bem esticado e firme a 2,20 - 2,50m de altura do solo, no sentido da linha de plantio. Amarrar uma das pontas de um fitilho de ráfia ou nylon na haste da planta, logo abaixo da segunda ou terceira folha e a outra no arame. À medida que a planta for crescendo, enrola-se a haste no fitilho.

Torna-se importante ressaltar que este último sistema tem sido utilizado preferencialmente em cultivos em ambiente protegido.

\subsubsection{Poda}

A poda consiste na retirada de partes da planta para promover o crescimento de outras. Segundo Salisbury e Ross (1985), devido à competição por nutrientes entre órgãos reprodutivos e vegetativos, um determinado estímulo como a retirada de partes da planta pode estimular o florescimento.

$\mathrm{Na}$ cultura do pepino, esta prática, apesar de bastante difundida pelos olericultores, é de utilidade controvertida (Cañizares, 1998; Filgueira, 2000). Pretendese, com a poda, favorecer o desenvolvimento de maior número de flores femininas, aumentando a produtividade, a precocidade e qualidade dos frutos (Sonnenberg, 1985). 
A técnica também melhora o arejamento da cultura, facilitando as pulverizações e o tutoramento. (Maroto, 1994).

Em geral, tem-se vários tipos de podas que serão esclarecidas a seguir.

No primeiro deles, eliminam-se as ramificações laterais e os frutos que se originem nos primeiros $40 \mathrm{~cm}$ da haste principal, conduzindo a planta em um fio de arame. A partir da haste principal, surgem os ramos secundários que crescerão sobre o arame e onde produzirão as flores femininas. Quando se pretende uma produção mais precoce, podem-se deixar as flores que aparecem na haste principal o que causa a diminuição da produção total. No segundo sistema de poda, são eliminadas as 4 ou as 5 primeiras brotações laterais a partir da base da planta. Nas próximas brotações que surgirão, faz-se a poda depois do aparecimento de uma folha, a partir de 20 a $25 \mathrm{~cm}$ do pequeno fruto formado na axila. Dependendo do vigor e/ou da capacidade de desenvolvimento da planta, quando a haste principal atingir o arame de suporte $( \pm 2$ metros), faz-se a eliminação da gema apical. Assim ocorre estímulo das brotações laterais. O terceiro sistema é aplicado em híbridos ginóicos ou predominantemente femininas e partenocárpicos, que geralmente produzem um fruto por internódio. Nesta poda, eliminam-se todas as ramificações laterais, formando-se todos os frutos sobre a haste principal a partir de 0,80 a 1,00 m. Quando a haste principal atinge 2,00 m, deixase que ela desça, apoiando-a sobre os fios de arame dispostos longitudinalmente, não se realizando a partir deste ponto a poda dos ramos laterais (Illescas \& Vesperinas, 1989; Maroto, 1994; Filgueira, 2000).

Estes tipos de poda dependem das condições climáticas do local e também do vigor da planta. Sendo assim, elas podem apresentar algumas variações.

\subsubsection{Cobertura do solo ("mulching")}

A cobertura do solo é um sistema de proteção, que oferece melhores condições para o desenvolvimento das plantas. Vários materiais podem ser utilizados e a escolha depende principalmente do grau de tecnologia do olericultor e da disponibilidade do material. 
As vantagens deste sistema são comuns a várias culturas. Dentre elas, pode-se destacar: maior renda líquida por área cultivada; aumento da produção total e produção precoce; conservação da umidade e da estrutura do solo; redução da amplitude térmica do solo; menor perda de nutrientes por lixiviação; controle de plantas daninhas e obtenção de produtos mais limpos e de maior qualidade (Passos, 1997; Robinson \& Decker-Walters, 1997; Martins et al., 1998; Martins, 2000).

$\mathrm{Na}$ cultura do pepino, o uso de cobertura tem significado uma alternativa de produção tanto em ambiente protegido como em cultivo convencional. Araújo \& Castellane (1996), analisando o comportamento da cultura do pepino com e sem o uso de cobertura de polietileno, verificaram que a produção total, em número e massa, e o comprimento e diâmetro dos frutos foram superiores no cultivo com cobertura. Estes resultados concordam com aqueles obtidos por Farias-Larios et al. (1994), que, comparando três tipos de plástico como cobertura de solo no cultivo do pepino em condições tropicais, verificaram que sua utilização promoveu aumento do crescimento das plantas, precocidade de produção e aumento do número de frutos/planta.

\subsubsection{Produção em ambiente protegido e cultivo em substrato.}

O pepino é considerado a segunda hortaliça mais importante no cultivo em ambiente protegido (Cañizares, 1998). Além do pepino, outras oleráceas têm sido beneficiadas com as possibilidades oferecidas por este tipo de cultivo.

Vários autores destacaram as vantagens do cultivo em ambiente protegido (Oliveira et al., 1997; Andriolo, 1999; Brandão Filho \& Callegari, 1999; Martins, 2000). Dentre elas, podemos citar aumento de produtividade, sendo que para algumas culturas o aumento de produção é de duas a três vezes quando comparado ao cultivo convencional (Tabela1); colheitas na entressafra, diminuindo a sazonalidade de produção e regularizando o abastecimento; precocidade na colheita e maior qualidade dos produtos. Essa atividade propicia o cultivo fora de época e em locais onde as condições climáticas são limitantes. Para culturas mais exigentes em temperatura, como é o caso do maxixe, a utilização de ambientes protegidos não restringe a época de plantio, uma vez que temperaturas mais altas podem ser obtidas mesmo em épocas ou regiões desfavoráveis. 
Tabela 1. Comparação da produtividade em $\mathrm{kg} / 1.000$ plantas entre cultivo em ambiente protegido e plantio tradicional.

\begin{tabular}{lcc}
\hline & Campo & Cultivo Protegido \\
\hline Tomate & 4.000 & 9.000 \\
Pepino & 2.000 & 8.000 \\
Pimentão & 2.000 & 6.000 \\
\hline
\end{tabular}

Fonte: Coordenadoria de Assistência Técnica Integral, 1997

Alguns problemas também têm sido detectados no cultivo em ambiente protegido. O intenso uso de uma pequena área acaba provocando problemas de salinização e de ordem fitossanitária. Segundo Trani et al. (1997) devido a estes problemas, vem-se observando uma expansão menos acentuada do cultivo protegido no Estado de São Paulo. O cultivo em substrato com fertirrigação pode ser uma alternativa para superar esses tipos de problemas (Berjon \& Murray, 1997; Carneiro Júnior et al., 2002). Blanc (1987), citado por Andriolo et al. (1999), descreve as vantagens dessa modalidade de cultivo como: manejo mais adequado da água, evitando a umidade excessiva em torno das raízes; fornecimento de nutrientes em doses e épocas apropriadas; redução dos riscos de salinização do meio radicular e da ocorrência de problemas fitossanitários. 


\title{
3 CULTIVO DE MAXIXE PAULISTA EM CANTEIROS COM COBERTURA DE POLIETILENO
}

\author{
Autora: VALÉRIA APARECIDA MODOLO \\ Orientador: Prof. Dr. CYRO PAULINO DA COSTA
}

\section{Resumo}

A partir do cruzamento de Cucumis anguria L. x Cucumis longipes Hook obtiveram-se, com ciclos de seleção massal intercalados a ciclos de endogamia, linhagens de maxixe que diferem do tipo comum pelas suas características de ausência de espiculosidade, tamanho de fruto e formato de folha não-lobulada semelhante ao pepino. Dez destas linhagens, eleitas como elites e denominadas Maxixe Paulista, foram avaliadas quanto ao comportamento e produção de frutos no sistema de cultivo com cobertura de polietileno e fertirrigação. O Maxixe Comum foi utilizado como testemunha. As mudas foram obtidas em bandejas de poliestireno expandido e depois transplantadas para linha central de canteiros cobertos com polietileno preto, adotandose espaçamento de 1,0 m entre plantas. As plantas foram conduzidas de modo rasteiro, com fertirrigação por gotejamento. O delineamento experimental foi blocos ao acaso, com quatro repetições e parcela de seis plantas. A produção foi expressa em número total de frutos/parcela, massa total de frutos/parcela e massa média de fruto. As colheitas, num total de 12, foram realizadas durante dois meses. As linhagens de Maxixe Paulista apresentaram uma massa média de fruto de 66 a 91\% maior que o tipo Comum. A produção em massa total de frutos não diferiu entre os dois tipos de maxixe. O cultivo em canteiros com cobertura de polietileno e fertirrigação por gotejamento proporcionou uma produtividade estimada de $51,89 \mathrm{t} \cdot \mathrm{ha}^{-1}$. 


\title{
PAULISTA GHERKIN CROPPING USING POLYETHYLENE MULCH BED
}

\author{
Author: VALÉRIA APARECIDA MODOLO \\ Adviser: Prof. Dr. CYRO PAULINO DA COSTA
}

\section{Summary}

New gherkin lines were derived from Cucumis anguria x Cucumis longipes crossing through mass selection cycles intercalated with inbreeding cycles. The new lines differ from the common types by their absence of prickles, greater fruit size and non-lobular shaped leaves, similar to cucumber ones. Ten of such lines, selected as elite ones and named as Paulista Gherkin, were evaluated fruit production under polyethylene covering and under fertigation growing system. The Common Gherkin was used as check. Seedlings were produced in expanded polypropylene trays and then transplanted to the bed center covered with black polyethylene. Plants were spaced out 1,0m apart from each other and conducted in a prostrate habit under drip fertigation. A randomized blocks experimental design with four replicates and six plants per plot was used. The production was expressed as total number of fruits/plot, total weight of fruits/plot and average fruit weight. A total of 12 harvests were carried out during two months. Paulista Gherkin fruits were, in average, 66 to $91 \%$ heavier than the Common Gherkin ones. Production of total weight of fruits, of two gherkin types did not differ. The use of polyethylene-covered bed and drip fertigation promoted an estimate yield of 51,89 t.ha ${ }^{-1}$.

\subsection{Introdução}

O maxixe (Cucumis anguria L.) é uma cultura de origem africana bastante cultivada no norte e nordeste do Brasil. As populações brasileiras caracterizam-se pela produção de frutos sem sabor amargo e com variações quanto à espiculosidade e ao tamanho, geralmente com massa média de 30g (Pimentel, 1985). Sua forma de consumo está associada à culinária tradicional do Nordeste, onde o fruto maduro é cozido com outros ingredientes, originando o prato típico denominado "maxixada". Apesar de não 
ser habitual, esta hortaliça também pode ser consumida in natura na forma de salada, substituindo com vantagem o pepino por ser menos indigesta. Sua maior potencialidade seria para o segmento de consumo em conserva na forma de picles (Baird \& Thieret, 1988; Koch \& Costa, 1991; Robinson \& Decker-Walters, 1997).

A partir do cruzamento interespecífico entre Cucumis longipes e cultivares de Cucumis anguria, Koch \& Costa (1991) iniciaram um programa de melhoramento de maxixe conseguindo, entre outras características, quadruplicar o massa do fruto. Após alguns ciclos de seleção massal, foram obtidas várias dezenas de linhagens de maxixe que diferem do tipo comum pela ausência de espiculosidade, maior tamanho de fruto e formato de folha não-lobulada semelhante ao pepino. Estas linhagens foram avaliadas (Modolo et al., 1999) e selecionadas dando origem a um novo tipo de maxixe que foi denominado Maxixe Paulista.

O sistema de cultivo do Maxixe Comum é, na sua maioria, obsoleto sendo raramente submetido ao cultivo convencional. É predominantemente coletado a partir de populações subespontâneas em roçados ou em plantios de subsistência (Paiva, 1984). Porém, a partir do momento que temos um novo produto como o Maxixe Paulista, destinado a outros segmentos de mercado, como na forma de salada ou para conserva, isto implica em modernização de sua tecnologia de produção.

Algumas técnicas de cultivo podem ser empregadas para promover aumento de produtividade e melhoria de qualidade de uma hortaliça. Dentre elas pode-se destacar o cultivo em canteiros com cobertura e uso de fertirrigação, como já vem sendo feito no cultivo do morango há mais de trinta anos. Atualmente, devido às vantagens que este sistema oferece, a adesão desta tecnologia de produção é total (Goto \& Duarte Filho, 1999).

Há pouco tempo, surgiram no mercado vários tipos de materiais para a cobertura de solo. Tessarioli Neto et al. (1994abc) compararam uma cobertura permeável, do tipo não-tecido, de cor preta, com a cobertura normalmente utilizada na cultura do morango. Foram avaliados temperatura, desenvolvimento vegetativo e produção. No tratamento com cobertura de polietilieno preto, houve maior aquecimento do solo, maior desenvolvimento vegetativo e, conseqüentemente, maior produção precoce. Nesta 
mesma linha de trabalho e também para a cultura do morango, Castellane et al. (1995) e Cortez et al. (1995) testaram polietileno preto e polipropileno cinza/preto tipo carpete, comparando-os ao solo descoberto. Estes autores verificaram que tanto a produção total dos frutos comerciais como sua massa média não foram influenciadas pelo uso de cobertura, porém, houve redução na quantidade de frutos de qualidade inferior em relação ao solo descoberto.

Segundo Paiva (1998), os efeitos da cobertura de canteiros para as diversas hortaliças são praticamente os mesmos: influencia o metabolismo das plantas, acelerando sua absorção radicular de água e nutrientes; protege o solo da erosão causada pelo excesso de água de irrigação ou de chuva; aumenta a temperatura do solo nos primeiros $10 \mathrm{~cm}$ de profundidade, favorecendo o desenvolvimento da planta; aumenta o teor de umidade do solo na região radicular; controla algumas espécies de plantas daninhas; aumenta a produção dos cultivos além melhorar a qualidade dos produtos obtidos. Nem sempre esses efeitos são simultâneos e, na sua maioria, é necessário verificar as interações entre prática olerícola e reação no desenvolvimento da hortaliça.

No cultivo convencional do maxixeiro, existem variações quanto à produtividade dependendo da época e do local de cultivo. Na Amazônia, no período de menor pluviosidade, porém, com irrigação e espaçamento de $3,00 \times 2,00 \mathrm{~m}$ entre plantas, as cultivares Maxixe Liso e Maxixe com espículos produziram 110 e 165 frutos/cova, com massa média de 37 e 38g/fruto, respectivamente (Pimentel, 1985). No Maranhão, a produtividade média é de 16 t.ha $^{-1}$, porém, no período chuvoso, reduz para aproximadamente 8-10 t.ha ${ }^{-1}$ (Martins, 1986). Em São Paulo, a produtividade é de 12 t.ha $^{-1}$, sendo cultivado preferencialmente de setembro a fevereiro (Melo \& Trani, 1998). Filgueira (2000), considerando de uma maneira geral, relata que a produtividade da cultura do maxixe se situa em torno de 4 - 5 t.ha ${ }^{-1}$.

Não foi encontrada nenhuma referência sobre cultivo de maxixe utilizando cobertura de canteiros com polietileno. No entanto, Leal et al. (2000) verificaram aumento da produtividade desta cultura quando se utilizou palha de palmeira como cobertura de canteiros. Neste sistema, estes autores verificaram uma produtividade de 17,78 tha ${ }^{-1}$ contrastando com 15,15 t.ha $^{-1}$ no sistema convencional. No Maxixe Paulista, 
o uso de plástico como cobertura de canteiros associado à fertirrigação poderia constituir um eficiente manejo para aumento da produção, qualidade de frutos e controle de ervas daninhas. Outro fator favorável seria a introdução deste cultivo como alternativa de rotação nas regiões produtoras de morango, onde os produtores, aproveitando a infraestrutura existente, plantariam maxixe nas épocas de entressafra.

O objetivo desta pesquisa foi verificar o comportamento e avaliar a produção de frutos de um conjunto de dez linhagens de Maxixe Paulista com relação ao manejo de cultivo em campo, utilizando filme de polietileno para cobertura de canteiros e fertirrigação.

\subsection{Material e Métodos}

O experimento foi instalado e conduzido de agosto a dezembro de 1999, no campo experimental do Departamento de Produção Vegetal da Escola Superior de Agricultura "Luiz de Queiroz", município de Piracicaba, São Paulo. Segundo a classificação de Köppen, o clima da região é Cwa: subtropical úmido, com três meses mais secos (jun./jul./ago.), chuvas de verão e seca de inverno, temperatura do mês mais quente maior que $22^{\circ} \mathrm{C}$ e média de $21,4^{\circ} \mathrm{C}$.

As mudas das linhagens designadas como L1, L2, L3, L4, L5, L6, L8, L42, L55 e L60 de Maxixe Paulista (Modolo et al.,1999) e do Maxixe Comum foram obtidas em bandejas de poliestireno expandido preenchidas com substrato GII, da empresa Gioplanta. Após 20 dias, as mudas foram transplantadas para bandejas de 72 células preenchidas com o mesmo substrato. O transplante para o campo ocorreu 47 dias após a semeadura, sendo as mudas dispostas no centro de canteiros com 1,20 m de largura, com espaçamento de 1,0 m entre plantas. Antes do transplante, foi realizado o preparo do solo constando de uma aração, duas gradagens e encanteiramento. Os canteiros foram cobertos com filme de polietileno preto de baixa densidade. $\mathrm{O}$ sistema de irrigação utilizado foi do tipo gotejo e a fertirrigação foi feita com o adubo N-P-K mais micronutrientes, conforme recomendação para cultura do pepino (Tabela 2). 
Tabela 2. Cronograma de adubação

\begin{tabular}{|c|c|c|c|}
\hline Período (dias) & Estágio da planta & Adubo (N-P-K) & Dose (g.L $\left.\mathrm{L}^{-1}\right)$ \\
\hline $1-15$ & Estabelecimento & Formulação 13-40-13 & 0,3 \\
\hline \multirow[t]{3}{*}{$16-30$} & \multirow[t]{3}{*}{ Crescimento } & Formulação 15-05-15 & 0,2 \\
\hline & & Nitrato de cálcio & 0,1 \\
\hline & & Nitrato de Magnésio líquido & 0,15 \\
\hline \multirow[t]{3}{*}{$31-45$} & \multirow{3}{*}{$\begin{array}{l}\text { Até o primeiro } \\
\text { fruto }\end{array}$} & Formulação 15-05-30 & 0,3 \\
\hline & & Nitrato de cálcio & 0,2 \\
\hline & & Nitrato de Magnésio líquido & 0,15 \\
\hline \multirow[t]{3}{*}{$46-60$} & \multirow[t]{3}{*}{ Produção } & Formulação 06-12-06 & 0,4 \\
\hline & & Nitrato de cálcio & 0,3 \\
\hline & & Formulação 12-12-36 & 0,9 \\
\hline
\end{tabular}

As plantas foram conduzidas de modo rasteiro. Quando as ramas laterais apresentavam cerca de 1,0 $\mathrm{m}$ de comprimento, foi feita a poda apical da haste principal para estimular a frutificação nos ramos laterias. O tratamento fitossanitário foi realizado de forma preventiva, visando ao controle de pragas e doenças fúngicas. A colheita dos frutos iniciou-se 80 dias após a semeadura, sendo realizada durante dois meses num total de 12 etapas. A produção foi expressa em número total de frutos/parcela e massa total de frutos/parcela, em quilograma. Posteriormente, foi calculado a massa média de fruto, em gramas, e produtividade/área, em t.ha ${ }^{-1}$. O delineamento experimental foi blocos ao acaso, com quatro repetições e parcela de seis plantas. Os resultados obtidos foram transformados segundo $\sqrt{x+0,5}$, para realização da análise de variância e comparação das médias nas etapas de colheita pelo teste de Dunnet. Posteriormente, as médias sem transformação foram comparadas pelo Teste Tukey a 5\% de probabilidade. 


\subsection{Resultados e Discussão}

Observa-se nas tabelas 3 e 4 que, para massa em $\mathrm{kg}$ de frutos/planta, na maioria das colheitas, não houve diferença entre as linhagens e o tipo Comum. Nas três primeiras colheitas, as linhagens L4 e L5 apresentaram comportamento similar, com produção de quatro a nove vezes inferior ao tipo Comum. Na décima colheita, houve um pico de produção do tipo Comum, sendo somente a linhagem L3 tão produtiva quanto ele.

Tabela 3. Massa de frutos/planta, em kg, de linhagens de Maxixe Paulista L1, L2, L3, L4, L5, L6, L8, L42, L55 e L60 e do tipo Comum (A), nas seis etapas iniciais de colheita. Piracicaba, ESALQ/USP, 1999.

\begin{tabular}{|c|c|c|c|c|c|c|}
\hline \multirow{2}{*}{$\begin{array}{l}\text { Tipos de } \\
\text { Maxixe }\end{array}$} & \multicolumn{6}{|c|}{ Massa (kg) de frutos/planta nas etapas de colheita } \\
\hline & $\mathbf{1}^{\mathrm{a}}$ & $2^{a}$ & $3^{\mathbf{a}}$ & $4^{\mathrm{a}}$ & $5^{a}$ & $6^{a}$ \\
\hline $\bar{A}$ & 0,09 & 0,18 & 0,38 & 0,62 & 0,78 & 0,31 \\
\hline L1 & 0,02 & $0,06 *$ & 0,19 & 0,41 & 0,71 & 0,44 \\
\hline $\mathrm{L} 2$ & 0,12 & 0,26 & 0,39 & 0,86 & 0,61 & 0,51 \\
\hline L3 & 0,09 & 0,22 & 0,35 & 0,77 & 0,67 & 0,50 \\
\hline L4 & $0,02 *$ & $0,06 *$ & $0,14 *$ & 0,52 & 0,40 & 0,36 \\
\hline L5 & $0,01 *$ & $0,03 *$ & $0,09 *$ & 0,28 & 0,43 & 0,45 \\
\hline L6 & 0,08 & 0,16 & 0,30 & 0,59 & 0,57 & 0,41 \\
\hline L8 & 0,04 & 0,13 & 0,29 & 0,64 & 0,68 & 0,59 \\
\hline L42 & $0,02 *$ & 0,07 & 0,19 & 0,49 & 0,52 & 0,33 \\
\hline L55 & 0,03 & 0,08 & $0,17 *$ & 0,57 & 0,60 & 0,63 \\
\hline L60 & 0,03 & 0,14 & 0,21 & 0,51 & 0,56 & 0,46 \\
\hline
\end{tabular}

Dentro da coluna, médias seguidas por $\left(^{*}\right)$ são significativamente diferente da testemunha (A) pelo teste de Dunnet a $5 \%$ de probabilidade. Dados transformados em $\sqrt{x+0,5}$.

Com relação ao número de frutos/planta, observa-se que, de maneira geral, nas quatro primeiras colheitas, o Comum produziu significativamente maior número de frutos que as linhagens, exceto L2, L3 e L6 (Tabela 5). Nas sexta e sétima colheitas, este comportamento não se manteve, pois as linhagens do Paulista foram equivalentes ao Comum (Tabelas 5 e 6). Na quinta, nona e principalmente na décima colheita, o Maxixe Comum mostrou ser altamente prolífico, quando nesta última sua produção em termos de número de frutos foi 3,5 vezes maior que a linhagem mais prolífica L6 e 9 vezes maior que a menos prolífica L60. Segundo Yokoyama \& Silva Júnior (1988), o ponto 
máximo de crescimento do fruto do Maxixe Comum ocorre em torno do décimo primeiro e décimo segundo dia após a antese. Para o Maxixe Paulista, este estádio de maturação ocorre aos vinte e cinco dias após a antese, dado que este apresenta uma formação lenta de sementes (Modolo \& Costa, 2000). Na última etapa de colheita, as linhagens foram equivalentes ao Comum, quanto a sua produção de frutos.

Tabela 4. Massa de frutos/planta, em kg, de linhagens de Maxixe Paulista L1, L2, L3, L4, L5, L6, L8, L42, L55 e L60) e do tipo Comum (A), nas seis etapas finais de colheita. Piracicaba, ESALQ/USP, 1999.

\begin{tabular}{ccccccc}
\hline $\begin{array}{c}\text { Tipos de } \\
\text { Maxixe }\end{array}$ & $\mathbf{7}^{\mathbf{a}}$ & \multicolumn{6}{c}{ Massa de frutos/planta nas etapas de colheita } \\
\hline $\mathbf{8}^{\mathbf{a}}$ & $\mathbf{9}^{\mathbf{a}}$ & $\mathbf{1 0}^{\mathbf{a}}$ & $\mathbf{1 1}^{\mathbf{a}}$ & $\mathbf{1 2}^{\mathbf{a}}$ \\
\hline A & 0,60 & 0,30 & 1,36 & 2,02 & 0,77 & 0,57 \\
L1 & 0,80 & 0,52 & 0,67 & $0,77 *$ & 0,70 & 0,77 \\
L2 & 0,81 & 0,56 & $0,44 *$ & $0,83 *$ & 0,70 & 0,57 \\
L3 & 1,08 & 0,86 & 0,79 & 1,10 & 1,05 & 0,94 \\
L4 & 0,78 & 0,59 & 0,96 & $0,64 *$ & 0,62 & 0,52 \\
L5 & 0,79 & 0,53 & 0,72 & $0,76 *$ & 0,69 & 0,74 \\
L6 & 0,90 & 0,71 & 1,17 & $1,04 *$ & 0,92 & 0,83 \\
L8 & 1,16 & 0,96 & 0,73 & $0,95 *$ & 1,12 & 0,96 \\
L42 & 0,92 & $1,13 *$ & 1,09 & $0,74 *$ & 0,63 & 0,50 \\
L55 & 1,21 & $1,22 *$ & 1,03 & $0,81 *$ & 0,89 & 0,79 \\
L60 & 0,89 & 0,69 & 0,72 & $0,46 *$ & 0,66 & 0,50 \\
\hline
\end{tabular}

Dentro da coluna, médias seguidas por $(*)$ são significativamente diferentes da testemunha (A) pelo teste de Dunnet a $5 \%$ de probabilidade. Dados transformados em $\sqrt{x+0,5}$. 
Tabela 5. Número de frutos/planta de linhagens de Maxixe Paulista L1, L2, L3, L4, L5, L6, L8, L42, L55 e L60 e do tipo Comum (A), nas seis etapas iniciais de colheita. Piracicaba, ESALQ/USP, 1999.

\begin{tabular}{cllcccc}
\hline $\begin{array}{c}\text { Tipos de } \\
\text { Maxixe }\end{array}$ & $\mathbf{1}^{\mathbf{a}}$ & \multicolumn{6}{c}{$\begin{array}{c}\text { Número de frutos/planta nas etapas de colheita } \\
\mathbf{2}^{\mathbf{a}}\end{array}$} & $\mathbf{3}^{\mathbf{a}}$ & $\mathbf{4}^{\mathbf{a}}$ & $\mathbf{5}^{\mathbf{a}}$ & $\mathbf{6}^{\mathbf{a}}$ \\
\hline A & 3,1 & 6,6 & 11,5 & 18,2 & 22,2 & 9,3 \\
L1 & $0,5 *$ & $1,3 *$ & $3,3 *$ & $7,0 *$ & $11,3 *$ & 7,6 \\
L2 & 2,6 & 4,8 & 7,0 & 14,0 & $11,0 *$ & 9,4 \\
L3 & 2,2 & 4,1 & 6,5 & 13,2 & $11,4 *$ & 8,9 \\
L4 & $0,5 *$ & $1,3 *$ & $2,5 *$ & $8,2 *$ & $7,2 *$ & 6,3 \\
L5 & $0,1 *$ & $0,7 *$ & $2,0 *$ & $5,2 *$ & $7,3 *$ & 7,9 \\
L6 & 2,3 & $3,5 *$ & 7,0 & 11,5 & $11,4 *$ & 7,5 \\
L8 & $0,9 *$ & $2,5 *$ & $5,5 *$ & 10,9 & 12,6 & 10,7 \\
L42 & $0,5 *$ & $1,6 *$ & $4,3 *$ & 13,0 & $10,9 *$ & 6,8 \\
L55 & $0,7 *$ & $1,7 *$ & $3,5 *$ & 11,0 & $11,0 *$ & 11,9 \\
L60 & $0,9 *$ & $2,8 *$ & $4,0 *$ & $8,6 *$ & $9,7 *$ & 8,4 \\
\hline
\end{tabular}

Dentro da coluna, médias seguidas por $\left(^{*}\right)$ são significativamente diferentes da testemunha (A) pelo teste de Dunnet a 5\% de probabilidade. Dados transformados em $\sqrt{x+0,5}$.

Tabela 6. Número de frutos/planta de linhagens de Maxixe Paulista L1, L2, L3, L4, L5, L6, L8, L42, L55 e L60 e do tipo Comum (A), nas seis etapas finais de colheita. Piracicaba, ESALQ/USP, 1999.

\begin{tabular}{|c|c|c|c|c|c|c|}
\hline \multirow{2}{*}{$\begin{array}{l}\text { Tipos de } \\
\text { Maxixe }\end{array}$} & \multicolumn{6}{|c|}{ Número de frutos/planta nas etapas de colheita } \\
\hline & $7^{\mathrm{a}}$ & $8^{\mathbf{a}}$ & $9^{a^{a}}$ & $10^{\mathrm{a}}$ & $11^{\mathrm{a}}$ & $12^{\mathrm{a}}$ \\
\hline$\overline{\mathrm{A}}$ & 15,6 & 8,4 & 41,1 & 56,9 & 20,0 & 13,3 \\
\hline L1 & 11,8 & 8,1 & $9,2 *$ & $11,5 *$ & 10,4 & 12,3 \\
\hline $\mathrm{L} 2$ & 13,3 & 9,7 & $7,5 *$ & $13,8 *$ & 12,9 & 13,1 \\
\hline L3 & 16,5 & 13,5 & $12,6 *$ & $16,0 *$ & 17,2 & 14,5 \\
\hline L4 & 12,3 & 10,5 & $12,3 *$ & $8,9 *$ & $9,6 *$ & 7,8 \\
\hline L5 & 12,8 & 9,0 & $12,1 *$ & $12,1 *$ & 12,0 & 12,6 \\
\hline L6 & 15,8 & 12,8 & $20,6 *$ & $16,5 *$ & 15,5 & 14,0 \\
\hline L8 & 18,3 & 16,4 & $11,7 *$ & $13,7 *$ & 20,3 & 15,5 \\
\hline L42 & 17,8 & $22,3 *$ & $20,9 *$ & $15,7 *$ & 12,0 & 9,0 \\
\hline L55 & 20,1 & $21,8 *$ & $17,3 *$ & $11,4 *$ & 15,6 & 13,8 \\
\hline L60 & 14,5 & 11,3 & $11,0 *$ & $6,4 *$ & 11,1 & 8,0 \\
\hline
\end{tabular}

Dentro da coluna, médias seguidas por $\left({ }^{*}\right)$ são significativamente diferentes da testemunha (A) pelo teste de Dunnet a $5 \%$ de probabilidade. Dados transformados em $\sqrt{x+0,5}$. 
Considerando-se o número de frutos produzidos em todas as etapas de colheita, verifica-se que as linhagens são equivalentes entre si e menos prolíficas que o Comum. Apenas as linhagens L3, L6, L8 e L55 foram semelhantes em termo de prolificidade ao tipo Comum (Tabela 7). Esta equivalência quanto à prolificidade das linhagens elite de maxixe pode ser explicada pelo processo seletivo que as originou. $\mathrm{O}$ critério mais importante neste processo foi o parâmetro massa média de fruto maduro. Na cultura do pepino, plantas com maior número de frutos tendem a produzir frutos com menor massa média e comprimento (Ramalho, 1973). Como no processo de seleção foi priorizado maior massa média de fruto, conseqüentemente o número total de frutos produzidos tenderá a diminuir, porém, sem redução na produção total (Simmonds, 1979).

Tabela 7. Número total (NTF), massa total (MTF) e massa média (MM) de frutos/parcela de 6 plantas, de Maxixe Paulista (L1; L2; L3; L4; L5; L6; L8; L42; L55 e L60) e do tipo Comum (A), após 12 colheitas. Piracicaba, ESALQ/USP, 1999.

\begin{tabular}{crcc}
\hline Tipos de maxixe & NTF & MTF (kg) & MM (g) \\
\hline A & $1306 \mathrm{a}$ & $47,91 \mathrm{a}$ & $36,78 \mathrm{~b}$ \\
L1 & $517 \mathrm{~b}$ & $36,44 \mathrm{a}$ & $70,05 \mathrm{a}$ \\
L2 & $656 \mathrm{~b}$ & $39,98 \mathrm{a}$ & $61,55 \mathrm{a}$ \\
L3 & $738 \mathrm{ab}$ & $50,53 \mathrm{a}$ & $68,96 \mathrm{a}$ \\
L4 & $462 \mathrm{~b}$ & $33,68 \mathrm{a}$ & $70,41 \mathrm{a}$ \\
L5 & $508 \mathrm{~b}$ & $33,13 \mathrm{a}$ & $64,07 \mathrm{a}$ \\
L6 & $752 \mathrm{ab}$ & $46,12 \mathrm{a}$ & $61,22 \mathrm{a}$ \\
L8 & $735 \mathrm{ab}$ & $49,45 \mathrm{a}$ & $67,23 \mathrm{a}$ \\
L42 & $674 \mathrm{~b}$ & $39,67 \mathrm{a}$ & $58,94 \mathrm{a}$ \\
L55 & $708 \mathrm{ab}$ & $48,31 \mathrm{a}$ & $68,65 \mathrm{a}$ \\
L60 & $512 \mathrm{~b}$ & $34,94 \mathrm{a}$ & $65,64 \mathrm{a}$ \\
C.V. & $25,45 \%$ & $27,46 \%$ & $8,04 \%$ \\
\hline
\end{tabular}

Dentro da coluna, médias seguidas pela mesma letra não diferem entre si pelo Teste de Tukey a $5 \%$ de probabilidade.

Considerando-se uma população de 6.500 plantas.ha $^{-1}$, estima-se, neste experimento, uma produtividade para o Maxixe Comum de 51,89 t.ha ${ }^{-1}$. A média de produtividade para o Estado de São Paulo em condições convencionais para uma 
população de 13.000 plantas.ha ${ }^{-1}$ tem sido de 12 t.ha $^{-1}$ (Melo \& Trani, 1998). Para as diferentes regiões produtoras de maxixe, a produtividade varia de 4 a 16 t.ha $^{-1}$ (Pimentel, 1985; Martins 1986; Filgueira 2000). Isto mostra ganhos de produtividade total no sistema de manejo com cobertura plástica de canteiros e fertirrigação por gotejamento, onde foi obtida uma produtividade de três a treze vezes maior que a descrita na literatura no cultivo convencional.

A característica que melhor caracteriza as diferenças entre o Maxixe Comum e o Paulista é a massa média do fruto. O Maxixe Comum apresenta massa média variando de 14,57 a 45,70g dependendo da cultivar, da época de plantio e da região produtora (Pimentel, 1985; Resende, 1998). Isto concorda com o encontrado neste experimento onde a média de massa/fruto foi de 36,78g. As linhagens de Maxixe Paulista apresentam massa média de fruto de 66 a 91\% maior que o do tipo Comum (Tabela 7).

Torna-se importante ressaltar que o sistema de comercialização no atacado de hortaliças é baseado em volume de frutos, enquanto a comercialização no varejo é feita com base na massa do produto. No Brasil, a embalagem mais utilizada na comercialização do Maxixe Comum é a caixa tipo "K", com 20kg do produto (Filgueira, 2000). Considerando-se uma massa média de fruto maior, seria necessário menor número de frutos para completar o mesmo volume de comercialização, o que traria economia de mão-de-obra tanto na colheita quanto na embalagem do produto. Outra vantagem do aumento da massa média do fruto é a inserção deste novo produto no consumo in natura na forma de salada. Tradicionalmente, para o preparo do Maxixe Comum, os frutos são raspados para retirada dos espinhos e da casca e, devido ao seu tamanho, estes são colocados inteiros para o cozimento com outros ingredientes. No Maxixe Paulista, além do uso na forma cozida, os frutos com casca lisa e dimensões maiores facilitam o corte em fatias, como é feito com o fruto de pepino, para o consumo em saladas.

Algumas considerações podem ser feitas quanto ao comportamento do cultivo do maxixe no manejo adotado. O espaçamento de $1,0 \mathrm{~m}$ entre plantas mostrou ser competitivo, com ampla cobertura do solo, o que dificultou o manuseio das plantas na fase final das etapas de colheita. O hábito de crescimento prostrado e a intensa 
ramificação da cultura fizeram com que as ramas crescessem para fora da cobertura de polietileno. Este comportamento fez com que houvesse pisoteio e danos nas ramificações ao longo dos espaços entre os canteiros, nas etapas finais de colheita. Com isso, as vantagens diretas na qualidade dos frutos oferecidas pelo uso da cobertura de solo foram restritas somente às primeiras etapas de colheita. Se fosse considerado o cultivo de maxixe como alternativa para produtores de morango, como cultura de entressafra, maiores estudos deveriam ser realizados para que a produção dos frutos seja concentrada em cima da cobertura.

\subsection{Conclusões}

- As linhagens de Maxixe Paulista apresentaram um massa média de fruto de 66 a 91\% maior que o tipo Comum;

- A produção em massa total de frutos não diferiu entre os dois tipos de maxixe;

- O cultivo em canteiros com cobertura de polietileno e fertirrigação por gotejamento proporcionou uma produtividade estimada de $51,89 \mathrm{t} \cdot \mathrm{ha}^{-1}$. 


\title{
4 CONDUÇÃO DE MAXIXE PAULISTA EM AMBIENTE PROTEGIDO
}

\author{
Autora: VALÉRIA APARECIDA MODOLO \\ Orientador: Prof. Dr. CYRO PAULINO DA COSTA
}

\section{Resumo}

Maxixe Paulista é um novo tipo de maxixe derivado originalmente do cruzamento de Cucumis anguria x Cucumis longipes, com características distintas de fruto e folhas. Avaliou-se o comportamento e a produção de três linhagens do Maxixe Paulista, cultivadas em vasos com substrato, em ambiente protegido, com tutoramento e podas. O tipo Comum foi utilizado como testemunha. As mudas foram obtidas em bandejas de poliestireno expandido e depois transplantadas para vasos de cinco litros contendo uma mistura de areia, vermiculita, e húmus. Em estrutura do tipo arco, os vasos foram colocados em 5 linhas duplas, com espaçamento de $0,5 \mathrm{~m}$ entre vasos e $1,0 \mathrm{~m}$ entre linhas. As plantas foram conduzidas tutoradas e com podas, utilizando o protocolo de cultivo de pepino em ambiente protegido. Para a irrigação, foi utilizado sistema de mangueiras de gotejamento do tipo espaguete e a fertirrigação foi feita com o adubo NP-K. O delineamento experimental foi de blocos ao acaso, com oito repetições e parcela de oito plantas. As características avaliadas foram número total de frutos/parcela, massa total de frutos/parcela e massa média de fruto. As colheitas, num total de 10, foram realizadas durante dois meses. A produção total em massa de frutos não diferiu entre os dois tipos de maxixe. As linhagens de Maxixe Paulista apresentaram uma massa média de fruto de 62 a 84\% maior que o tipo Comum. A linhagem 2 foi tão produtiva, em termo de massa total, quanto o tipo Comum, porém, sua massa média de fruto foi 
$75 \%$ maior. A planta de maxixe mostrou ser inadequada para condução no protocolo de tutoramento e podas da cultura do pepino. O maxixe apresentou uma forte supressão da dominância apical predominando uma concentração de frutificação na região basal da planta o que tornou a poda trabalhosa e ineficaz.

\title{
PAULISTA GHERKIN CROP MANAGEMENT UNDER HIGHT PLASTIC TUNNEL.
}

\author{
Author: VALÉRIA APARECIDA MODOLO \\ Adviser: Prof. Dr. CYRO PAULINO DA COSTA
}

\section{Summary}

Paulista Gherkin is a new gherkin type derived from Cucumis anguria x Cucumis longipes, crossing with distinct fruit and leaf characteristics. The behavior of three Paulista Gherkin lines was evaluated. Plants were grown in pots with substrate, under hight plastic tunnel and they were trellised and pruned. Common Gherkin was used as control. Seedlings were produced in expanded polypropylene trays and then transferred to 5-liter pots containing a mixture of sand, vermiculite and humus. Inside a high plastic tunnel, the pots were arranged within 5 double rows and displayed $0.5 \mathrm{~m}$ from each other, with $1.0 \mathrm{~m}$ between lines. Plants were trellised and pruned according to the cucumber cultivation protocol under protected environment. Drip irrigation system was made with spaghetti type, and N-P-K fertlizer was used for fertigation. A randomized blocks design with eight replicates and eight plants per plot was used. Evaluated characteristics were total number of fruits/plot, total weight of fruits/plot and average fruit weight. A total of ten harvests were carried out during two months. The total production expressed as the total weight of fruits did not differ between the two gherkin types. Paulista Gherkin fruits were, in average, 62 to $84 \%$ heavier than the Common Gherkin ones. The line number 2 of Paulista Gherkin was as productive as the Common type, considering the total weight of fruits. However, its average fruit weight was $75 \%$ 
superior. Gherkin plants showed to be inadequate for being conducted as suggested by the cucumber cultivation protocol. Gherkin plant presented strong suppression of its apical dominance resulting a higher fruit concentration in the plants' basal region, making the pruning inefficient.

\subsection{Introdução}

As culturas protegidas tornaram-se um sistema de produção muito difundido dentro da olericultura. A necessidade de fornecer produtos de boa qualidade durante todos os períodos do ano levou os produtores à construção de abrigos para a proteção das culturas das adversidades climáticas como vento, granizo, altas precipitações e temperaturas extremas (Andriolo, 1999). Essa atividade propicia o cultivo fora de época e em locais onde as condições climáticas são limitantes. Para culturas mais exigentes em temperatura, como é o caso do maxixe, a utilização de ambientes protegidos não restringe a época de plantio, uma vez que temperaturas mais altas podem ser obtidas mesmo em épocas ou regiões com temperaturas amenas.

Vários autores destacaram as vantagens do cultivo em ambiente protegido (Oliveira et al., 1997; Andriolo, 1999; Brandão Filho \& Callegari, 1999; Martins, 2000). Dentre elas, pode-se citar aumento de produtividade, sendo para algumas culturas de duas a três vezes maior que a do cultivo convencional; colheitas na entressafra, diminuindo a sazonalidade de produção e regularizando o abastecimento; precocidade na colheita; maior qualidade dos produtos. Entretanto, o intenso uso de uma pequena área no cultivo protegido acaba gerando problemas de salinização e de ordem fitossanitária. Segundo Trani et al. (1997), devido a estes problemas, vem se observando uma expansão menos acentuada do cultivo protegido no Estado de São Paulo. O cultivo em substrato com fertirrigação pode ser uma alternativa para superar esses tipos de problemas (Berjon \& Murray, 1997; Carneiro Júnior et al., 2002). Blanc (1987), citado por Andriolo et al. (1999), descreve as vantagens dessa modalidade de cultivo como: manejo mais adequado da água, evitando a umidade excessiva em torno das raízes; 
fornecimento de nutrientes em doses e épocas apropriadas; redução dos riscos de salinização do meio radicular e da ocorrência de problemas fitossanitários.

Segundo Goto ${ }^{2}$, para se obter melhor resposta no manejo em ambiente protegido, é imprescindível conhecer as condições básicas necessárias para que a planta tenha um bom crescimento e desenvolvimento. As interações entre planta, ambiente e práticas fitotécnicas utilizadas condicionam respostas quantitativas, em rendimento em $\mathrm{kg} . \mathrm{m}^{-2} \mathrm{e}$ qualitativas, tais como melhoria das características organolépticas e nutricionais (Martins et al., 1998). No cultivo de pepino, estas interações são bastante conhecidas. Conseqüentemente, a tecnologia de produção em ambiente protegido promove altos rendimentos por unidade de área com produtos de alta qualidade fazendo com que esta hortaliça ocupe o segundo lugar em importância nesse sistema de cultivo (Trani et al., 1997; Cañizares, 1998). No gênero Cucumis, além do pepino, o melão é uma opção para os produtores em ambiente protegido. O melão apresenta como vantagens a produção de frutos com excelente aspecto visual e grande teor de sólidos solúveis, apresentando boa cotação e podendo, por isso, ser cultivado em pequenas áreas com boa lucratividade (Brandão Filho \& Vasconcellos, 1998).

$\mathrm{Na}$ cultura do Maxixe Comum o sistema de cultivo tradicional utiliza pouquíssimas práticas fitotécnicas. Raramente esta cultura é submetida ao cultivo convencional e, na maioria das vezes, é coletada a partir de populações subespontâneas em roçados ou em plantios de subsistência (Paiva, 1984). No cultivo tradicional, a planta de maxixe é conduzida rasteira com os frutos em contato com o solo que induz seu estiolamento e depreciação, provocando um defeito denominado "barriga branca".

Maxixe Paulista é um novo tipo de maxixe derivado originalmente do cruzamento de Cucumis anguria x Cucumis longipes, com características distintas de fruto e folhas. Modolo \& Costa (2001b) ressaltam que a característica que melhor diferencia o Paulista e o tipo Comum é a massa média do fruto. O Maxixe Paulista apresenta massa média de 66 a 91\% maior que o Comum. Esta nova hortaliça necessita de uma adequação de tecnologia de produção usando protocolos utilizados em espécies

\footnotetext{
${ }^{2}$ citado por Brandão Filho \& Callegari (1999).
} 
já cultivadas com sucesso em ambiente protegido, com poda e tutoramento. Para o Maxixe Comum, poucos trabalhos têm sido feitos com relação a este sistema de cultivo, porém, alguns autores já mostraram a potencialidade deste tipo cultivo. Leal et al. (2000) verificaram que o cultivo tutorado do maxixe permitiu melhorar drasticamente a qualidade dos frutos colhidos, reduzindo em mais de $95 \%$ a ocorrência de "barriga branca". Leal \& Rego (2001), estudando espaçamentos em cultivos de maxixe em ambiente com $50 \%$ de sombra conduzidos de forma tutorada, verificaram produtividade de $0,6 \mathrm{~kg} \cdot \mathrm{m}^{-2}$. Marouelli et al. (2001), verificando o efeito residual de nitrogênio na produção de maxixe em ambiente protegido, constataram uma produtividade de $4,44 \mathrm{~kg} \cdot \mathrm{m}^{-2}$. Ambos os autores concluíram que o sistema de cultivo tutorado promoveu melhoria na qualidade dos frutos. Vale ressaltar que a produtividade média para o cultivo convencional varia de 4 a 16 t.ha $^{-1}$, ou seja 0,4 a $1,6 \mathrm{~kg} \cdot \mathrm{m}^{-2}$.

O objetivo deste trabalho foi avaliar o comportamento de linhagens de Maxixe Paulista cultivadas em substrato, com práticas de tutoramento e poda baseadas na tecnologia de produção de pepino em ambiente protegido.

\subsection{Material e Métodos}

$\mathrm{O}$ experimento foi instalado e conduzido em ambiente protegido, no período de agosto a dezembro de 2000, no Departamento de Produção Vegetal, da Escola Superior de Agricultura "Luiz de Queiroz", no município de Piracicaba. A estrutura foi do tipo arco, com área de $154 \mathrm{~m}^{2}$ ( 7 x 22m), coberta de plástico transparente de $150 \mu$ e laterais revestidas com telado de $30 \%$ de sombreamento.

Foram avaliadas quatro linhagens elite de Maxixe Paulista denominadas L1, L2 e L60 (Modolo et al.,1999) e uma cultivar de Maxixe Comum (A) como testemunha.

As mudas foram obtidas em bandejas de poliestireno expandido e, após 38 dias, transplantadas para vasos de cinco litros contendo uma mistura de areia, vermiculita, e húmus na proporção de 7:2:1, respectivamente. Foi feita desinfestação do substrato antes do transplante com uma solução de hipoclorito de sódio a 3\%. Os vasos foram colocados em 5 linhas duplas, com espaçamento de $0,5 \mathrm{~m}$ entre vasos e $1,0 \mathrm{~m}$ entre linhas. Para o tutoramento das plantas, na parte interna do túnel alto, foram instalados mourões de 
madeira de 2,0 $\mathrm{m}$ de altura e distanciados 2,0 $\mathrm{m}$ um do outro, onde foram esticados ao longo da linha de cultivo arames número 14 com auxílio de catracas. As plantas foram conduzidas verticalmente, sendo presas em sua base a uma fita de ráfia e, na outra extremidade, ao fio de arame. A poda adotada foi baseada no protocolo utilizado para o cultivo de pepino, onde foram eliminadas as 7 primeiras brotações laterais (hastes secundárias) a partir da base da haste principal. Nas próximas brotações, fez-se a poda após o aparecimento do terceiro fruto na haste secundária. Não foi feita eliminação da parte apical da haste principal após alcançar o fio de arame.

Para a irrigação, foi utilizado sistema de mangueiras de gotejamento do tipo espaguete e a fertirrigação foi feita com o adubo N-P-K mais micronutrientes, na dosagem recomendada para o cultivo de pepino (Tabela 8). A freqüência de irrigação e os volumes de água fornecidos foram estimados de forma a repor o consumo pela transpiração das plantas e, ao mesmo tempo, para restabelecer o volume retido na capacidade máxima de retenção do substrato. Para que não houvesse salinização do substrato, a condutividade elétrica (EC) da solução foi monitorada e ajustada a uma faixa de 1,0 a 1,5 mS em cada fertirrigação. Em intervalos de fertirrigações sucessivas, foi efetuada somente a irrigação das plantas.

Tabela 8. Cronograma de adubação

\begin{tabular}{cccc}
\hline Período (dias) & Estádio da planta & Adubo (N-P-K) & Dose (g.. $\mathbf{~}^{\mathbf{1}}$ ) \\
\hline $1-15$ & Estabelecimento & Formulação 13-40-13 & 0,3 \\
$16-30$ & Crescimento & Formulação 15-05-15 & 0,2 \\
& & Nitrato de cálcio & 0,1 \\
\multirow{2}{*}{$31-45$} & Até o primeiro & Nitrato de Magnésio líquido & 0,15 \\
& fruto & Formulação 15-05-30 & 0,3 \\
& & Nitrato de cálcio & 0,2 \\
$46-60$ & Produção & Nitrato de Magnésio líquido & 0,15 \\
& & Formulação 06-12-06 & 0,4 \\
& & Nitrato de cálcio & 0,3 \\
& & Formulação 12-12-36 & 0,9 \\
\hline
\end{tabular}


O tratamento fitossanitário foi realizado de forma preventiva, visando ao controle de doenças fúngicas como míldio (Pseudoperonospora cubensis) e pragas, principalmente mosca branca (Bemisia spp.).

O maxixeiro é um planta alógama, monóica, que depende da polinização principalmente entomófila para o desenvolvimento dos frutos. Como a estrutura de plástico permaneceu totalmente fechada na fase de florescimento, no seu interior foi colocada uma caixa com abelhas para promover a polinização.

A colheita iniciou-se 75 dias após a semeadura sendo realizada em 10 etapas, por um período de 2 meses. A produção foi expressa em número total de frutos/parcela e massa total de frutos/parcela, em quilograma. Posteriormente, calculou-se o massa média de fruto, em gramas, e produtividade/área, em $\mathrm{kg} /$ planta. O delineamento experimental foi blocos casualizados, com oito repetições e cada parcela constou de oito plantas. Foi realizada análise de variância e as médias foram comparadas pelo Teste de Tukey a $5 \%$.

\subsection{Resultados e Discussão}

Houve diferentes picos de produção de linhagens de Maxixe Paulista e do tipo Comum durante as etapas de colheita. No Maxixe Comum, o primeiro pico de produção ocorreu já na segunda colheita (Figuras 3 e 4). Para as linhagens, este foi um pouco mais tardio, ou seja, a partir da terceira colheita.

O desenvolvimento do fruto do Maxixe Comum é mais rápido que o do Paulista, como observado por Modolo \& Costa (2000), promovendo uma produção mais precoce. Segundo Robinson \& Decker-Walters (1997), algumas cucurbitáceas apresentam características fisiológicas e genéticas de espécies silvestres. A formação rápida de sementes nos frutos do tipo Comum pode ser considerada uma característica mais primitiva, que contribui para disseminação e manutenção do cultivo subespontâneo ou em condições silvestres. Nas linhagens de Maxixe Paulista, a distribuição da produção ao longo das colheitas foi bastante similar, sendo observados dois picos de produção, na terceira e quinta colheita. Este comportamento é esperado, pois os critérios seletivos ao longo dos ciclos de melhoramento foram os mesmos, resultando em um grupo de 
linhagens elites similares quanto às características de produção. Quanto às características de hábito de florescimento e frutificação, observa-se, contudo, que as linhagens de Maxixe Paulista são marcadamente mais tardias que o tipo Comum.

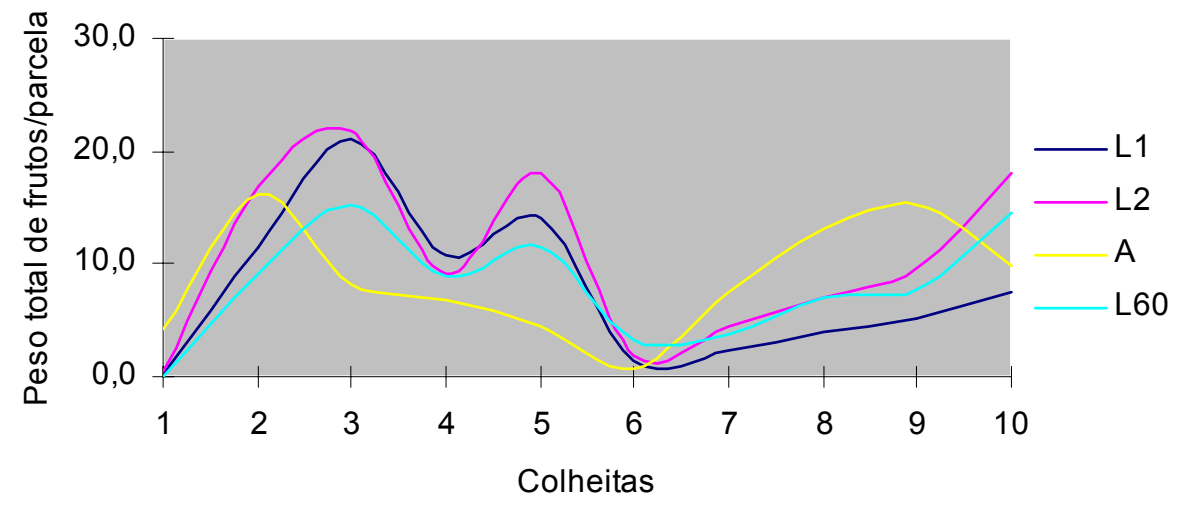

Figura 3 - Massa total $(\mathrm{kg})$ de frutos/parcela de 8 plantas das linhagens L1, L2 e L60 de Maxixe Paulista e do tipo Comum (A), durante as 10 etapas de colheita. ESALQ/USP - Piracicaba, 2000.

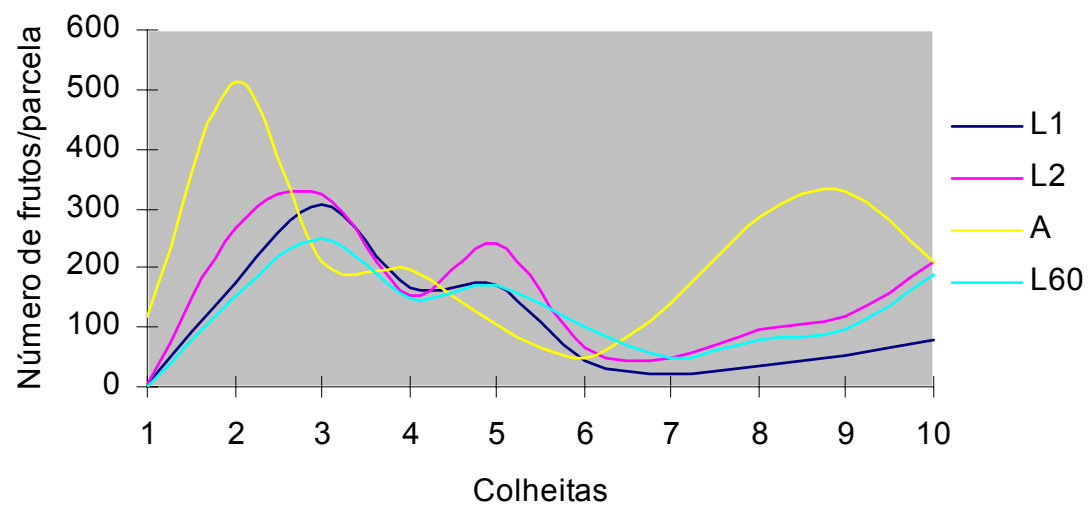

Figura 4 - Número total de frutos/parcela de 8 plantas das linhagens L1, L2 e L60 de Maxixe Paulista e do tipo Comum (A), durante as 10 etapas de colheita. ESALQ/USP - Piracicaba, 2000. 
O Maxixe Comum apresenta maior prolificidade expressa em número total de frutos, com valores entre 48,8\% e 70,7\% superiores às quatro linhagens do Paulista (Tabela 9). A produção das linhagens com relação ao massa total em quilogramas foi equivalente à do tipo Comum .

Tabela 9. Número total (NTF), massa total (MTF), massa média (MM) de frutos/parcela de 8 plantas e produtividade estimada (PE) das linhagens de Maxixe Paulista (L1, L2, L60) e do tipo Comum (A), após 10 etapas de colheitas. ESALQ/USP - Piracicaba, 2000.

\begin{tabular}{clllllc}
\hline Tipos de maxixe & NTF & MTF (kg) & PM (kg) & PE (kg/planta) \\
\hline A & $270,12 \mathrm{a}$ & $10,80 \mathrm{ab}$ & 39,80 & $\mathrm{c}$ & 1,4 \\
L1 & 132,00 & $\mathrm{~b}$ & $9,70 \mathrm{~b}$ & $73,32 \mathrm{a}$ & 1,2 \\
L2 & 191,00 & $\mathrm{~b}$ & $13,50 \mathrm{a}$ & 69,77 & $\mathrm{ab}$ & 1,7 \\
L60 & 154,37 & $\mathrm{~b}$ & $10,10 \mathrm{~b}$ & 64,79 & $\mathrm{~b}$ & 1,3 \\
C.V. & $16,55 \%$ & $19,63 \%$ & $4,27 \%$ & \\
\hline
\end{tabular}

Médias seguidas pela mesma letra não diferem entre si pelo Teste de Tukey a $5 \%$ de probabilidade.

Conforme relatado por Modolo \& Costa (2001b), a característica que melhor diferencia o Maxixe Paulista do Comum é a massa média do fruto. Isto também foi constatado no sistema de cultivo em ambiente protegido, pois a massa média de fruto das linhagens foram de 62 a 84\% superiores ao tipo Comum.

A linhagem L2 destaca-se pelo seu desempenho em duas das três características observadas. Quanto à produção total, ela é tão produtiva quanto o tipo Comum, porém, seu massa média de fruto é $75 \%$ maior.

A produtividade estimada de Maxixe Comum neste sistema de condução e cultivo em ambiente protegido foi de $1,4 \mathrm{~kg} /$ planta. Com a densidade de plantas utilizada no experimento, estima-se uma produtividade de 3,6 $\mathrm{kg} . \mathrm{m}^{-2}$. Marouelli et al. (2001), estudando o efeito residual de fontes de nitrogênio no cultivo de maxixe tutorado em rede agrícola, sem podas e em ambiente protegido, obteve produtividade de $4,4 \mathrm{~kg} . \mathrm{m}^{-2}$. Estes resultados são superiores aos encontrados por Leal et al (2001) que, no cultivo 
tutorado em ambiente com 50\% de sombra, obtiveram produção variando de 0,19 a 0,6 $\mathrm{kg} \cdot \mathrm{m}^{-2}$.

O manejo da planta de maxixe tutorada, com podas e em ambiente protegido, trouxe algumas dificuldades na condução do experimento. A planta de maxixe, embora sendo do mesmo gênero que o pepino, não teve a mesma resposta ao protocolo de podas das suas hastes laterais. Tanto no Maxixe Paulista como Comum, há uma forte supressão da dominância apical e forte estímulo da brotação lateral na parte basal da planta. Sendo assim, à medida que se efetuava a poda das hastes secundárias, o crescimento apical da planta não era estimulado e sim ocorria o surgimento de uma nova brotação lateral secundária, terceária ou até quaternária (Figura 5). A concentração de brotação e frutificação na região basal da planta fez com que houvesse pisoteamento das ramas laterais nas etapas finais de colheita. Isto mostra a dominância do caráter silvestre e pouco domesticado do maxixe em relação ao pepino, que, aliás, é a espécie de Cucumis mais domesticada e submetida a intensivos processos de melhoramento. Nas modernas variedades ginóicas de pepino, a frutificação ocorre principalmente na haste principal, com domínio sobre as brotações laterais (Maroto, 1995).

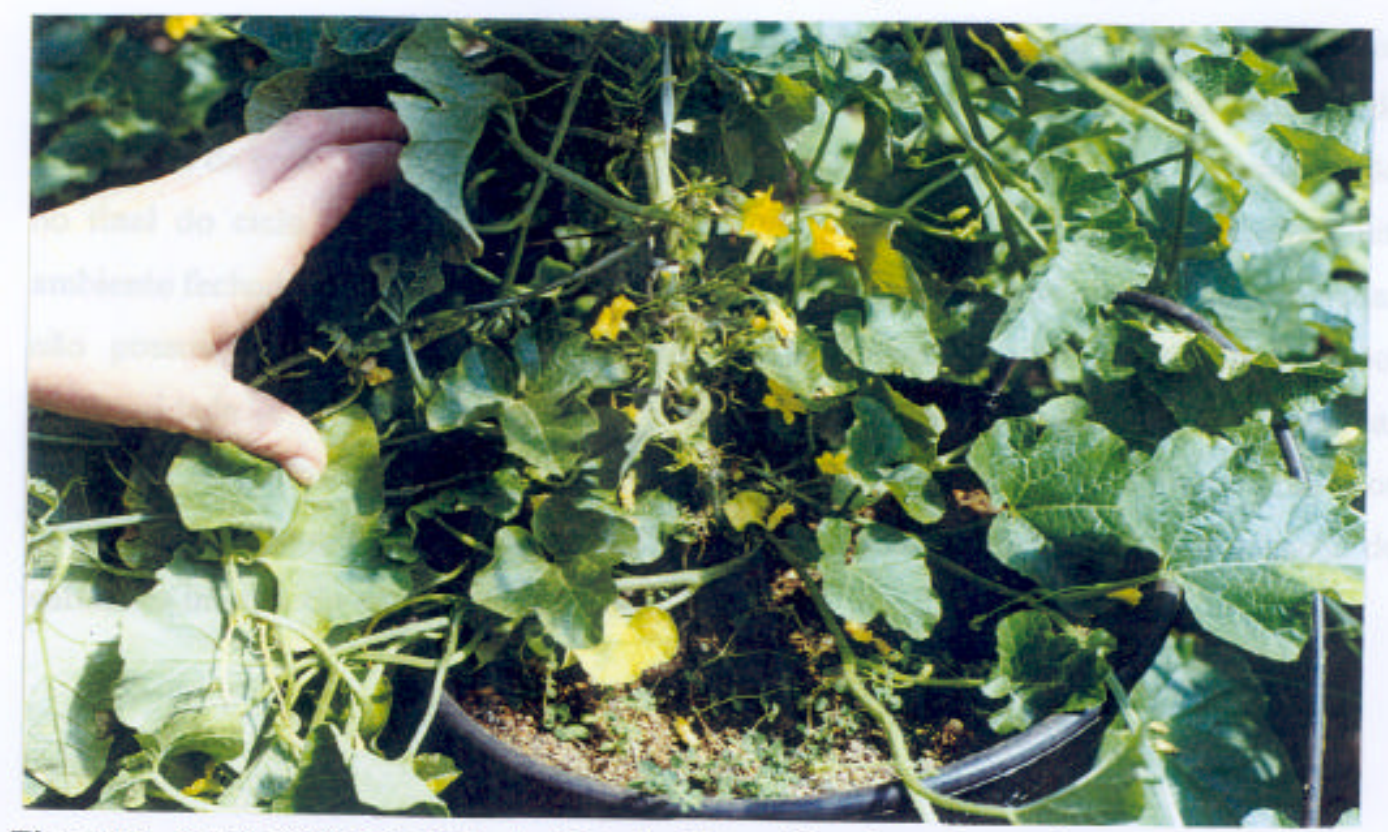

Figura 5 - Predominância da brotação lateral basal da planta de maxixe 
A grande vantagem do cultivo em ambiente protegido e condução com tutoramento e podas é a regularidade de produção, com o máximo de qualidade dos frutos. Uma das possibilidades de adequar a planta de maxixe neste sistema seria o tutoramento em rede agrícola sem o uso de podas. Neste caso, a rede facilitaria o tutoramento vertical e horizontal das hastes secundárias e terceárias, retirando os frutos do contato com o solo, melhorando sua qualidade e facilitando a colheita.

Outra dificuldade encontrada em ambiente protegido foi o manejo da caixa de abelhas para a polinização. Esta prática tem sido descrita por vários autores, tanto na polinização de pepino quanto na de melão, quando cultivados em ambiente protegido (Maroto, 1995; Robinson \& Decker-Walters, 1997; Cañizares, 1998). No cultivo de pepino, o uso de híbridos partenocárpicos dispensa a necessidade de agentes polinizantes. No cultivo de melão, o período de polinização é feito de maneira concentrada, pois são deixados de 3 a 4 frutos/planta. Neste caso, a presença de polinizadores ocorre por um período curto de tempo. No cultivo de maxixe, como são realizadas colheitas múltiplas, o período de florescimento e frutificação pode se estender por meses. As abelhas colocadas no interior do ambiente protegido foram eficientes na polinização, porém, com o tempo, houve uma redução considerável no número de indivíduos da colmeia, o que provocou a má formação de frutos pela falta de polinização no final do ciclo da cultura. Segundo Marchini ${ }^{3}$, o manejo da caixa de abelhas em ambiente fechado ainda precisa ser melhor elucidado, uma vez que abelhas africanizadas não possuem o mesmo comportamento das européias, quanto ao hábito de vôo, agressividade e comportamento de polinização. Uma alternativa para contornar problema da polinização seria a abertura das cortinas e/ou telados laterais nos horários propícios para permitir a entrada de abelhas externas, sem a necessidade de colocação de caixas no interior do ambiente protegido.

\footnotetext{
${ }^{3}$ Marchini, L.C. Comunicação pessoal, 2002.
} 


\subsection{Conclusões}

- A produção total em massa de frutos não diferiu entre os dois tipos de maxixe;

- As linhagens de Maxixe Paulista apresentaram um massa média de fruto de 62 a $84 \%$ maior que o tipo Comum;

- A planta de maxixe mostrou ser inadequada para condução no protocolo de tutoramento e o das da cultura do pepino. 


\title{
5 CONDUÇÃO DE HÍBRIDOS DE MAXIXE PAULISTA EM REDE AGRÍCOLA
}

\author{
Autora: VALÉRIA APARECIDA MODOLO \\ Orientador: Prof. Dr. CYRO PAULINO DA COSTA
}

\section{Resumo}

A partir do cruzamento de Cucumis anguria x Cucumis longipes, obtiveram-se, com ciclos de seleção massal intercalados a ciclos de endogamia, linhagens de maxixe que diferem do tipo comum pelas suas características de ausência de espiculosidade, maior tamanho de fruto e formato de folha não-lobulada semelhante ao pepino. Foram avaliadas quatro destas linhagens e seis híbridos simples, quanto ao comportamento e produção de frutos no sistema de cultivo tutorado em rede agrícola. As mudas foram obtidas em bandejas de poliestireno expandido com 128 células e, posteriormente, transplantadas para linha central de canteiros de 1,20 m de largura. As plantas foram conduzidas sem podas e tutoradas em rede agrícola com malha de $0,10 \mathrm{~m} \times 0,10 \mathrm{~m}$. $\mathrm{O}$ delineamento experimental foi blocos casualizados, com quatro repetições e parcela de sete plantas. A produção foi expressa em número e massa total de frutos/parcela. Avaliaram-se características de fruto como comprimento, largura e espessura de polpa, em amostragem de 5 frutos/parcela, em duas colheitas. A produção e a qualidade dos frutos dos híbridos foram equivalentes à das linhagens. A rede agrícola se mostrou adequada para o cultivo de Maxixe Paulista na forma tutorada. A concentração da frutificação ocorreu nas hastes secundárias e terceárias, cujas gavinhas mantiveram as plantas presas à rede. Esta técnica de condução facilita a colheita e melhora a qualidade dos frutos. 


\title{
HYBRID PAULISTA GHERKINS GROWN ON TRELLISED NET
}

\author{
Author: VALÉRIA APARECIDA MODOLO \\ Adviser: Prof. Dr. CYRO PAULINO DA COSTA
}

\section{Summary}

New gherkins lines were obtained from the crossbreeding between Cucumis anguria x Cucumis longipes through mass selection intercalated with inbreeding cycles. New lines differ from the common type by their absence of prickles, greater fruit size and non-lobular shaped leaves, similar to cucumber ones. Four of such lines and six simple hybrids were evaluated for their yield and fruit production under the trellised net cultivation system. Seedlings were produced in expanded polypropylene trays, containing 128 cells, and then transplanted to the center of $1,20 \mathrm{~m}$ beds. Plants were conducted without pruning on a $0,10 \mathrm{~m}$ x $0,10 \mathrm{~m}$ trellised net. A randomized blocks experimental design with four replicates and seven plants per plot was used. The production was expressed as the number and total weight of fruits/plot. Length, width and pulp thickness fruits were evaluated, with five sampled ones per plot for two harvests. Hybrids and lines were equivalent for production and fruits qualities. The trellised net showed to be suitable for the growing of Paulista Gherkin to support plants. Fruit concentration occurred in the secondary and tertiary lateral branch and their tendrils hold plants on the net. It is a trellis technique that mate harvest easier and improved fruit quality.

\subsection{Introdução}

Maxixe Paulista é um novo tipo de maxixe derivado originalmente do cruzamento de Cucumis anguria x Cucumis longipes, com características distintas de fruto e folhas. Segundo Modolo \& Costa (2001ab), a característica que melhor o diferencia das variedades comuns é a massa média de fruto, sendo até $91 \%$ superior. Apesar das linhagens elites apresentarem comportamento semelhante em termos de 
produção total e massa média de frutos, algumas características são peculiares a cada uma delas. Dentre estas, pode-se destacar formação lenta de semente, maior espessura de polpa de fruto, prolificidade e dormência de sementes. As cucurbitáceas são conhecidas por não apresentarem depressão do vigor quando submetidas à endogamia (Robinson \& Decker-Walters, 1999; Maluf, 2001). Contudo, a utilização de híbridos é amplamente difundida na cultura do pepino, onde a combinação de genes de qualidade de frutos ou de resistência a doenças é mais vantajoso que a heterose. A combinação de características através de produção de híbridos de Maxixe Paulista poderia ser uma alternativa para aumentar a qualidade de frutos e/ou a produção.

No cultivo tradicional a planta de maxixe desenvolve-se de maneira prostrada, com baixa produtividade e seus frutos, devido ao contato com o solo, apresentam-se danificados, desuniformes e estiolados, conhecidos como "barriga branca", o que deprecia sua qualidade (Martins 1986). Sendo o Maxixe Paulista um novo produto destinado aos segmentos de consumo in natura na forma de salada, em conserva ou cozido como abobrinha, existe a necessidade de adequar sua tecnologia de produção.

Segundo Filgueira (2000), a condução tutorada apresenta algumas consideráveis vantagens: favorece o controle fitossanitário, facilita alguns tratos culturais, melhora a qualidade do fruto, aumenta a longevidade da planta, alonga o período produtivo, favorece a colheita parcelada e possibilita produtividade mais elevada. Diversos protocolos de podas e tutoramento são utilizados em culturas hortícolas como pepino, melão e tomate, tanto em ambiente protegido ou não. Na cultura do pepino, o tutoramento tem grande importância para maximizar a produção e qualidade de frutos. Nesta cultura, esta prática promove um aumento de 3 a 5 vezes na produção quando comparada ao cultivo rasteiro (Alvarenga, 1982; Illescas \& Vesperinas, 1989). No caso do Maxixe Paulista, não houve resposta positiva quando a cultura foi submetida a um dos protocolos de tutoramento e podas da cultura de pepino (Modolo \& Costa, 2001b). Esta inadequação foi devido à forte supressão da dominância apical e estímulo da ramificação basal, concentrando a maior produção de fruto nas hastes secundárias e terciárias do terço basal da planta. No entanto, Leal et al. (2000) verificaram que, no cultivo tutorado do Maxixe Comum com fio de ráfia, a total distribuição da luz por todos 
o lados do fruto proporcionou menor percentual de frutos com "barriga branca", com incremento de sua qualidade. Marouelli et al. (2001), avaliando o efeito residual de nitrogênio na produção de maxixe em ambiente protegido, utilizou rede agrícola para tutoramento das plantas. Estes autores verificaram porcentagem média de $6,4 \%$ de frutos com "barriga branca" e $0,1 \%$ de frutos refugo.

O tutoramento em rede agrícola, sem o uso de podas, poderia ser uma alternativa de manejo nesta cultura. Neste caso, a rede facilitaria o tutoramento vertical e horizontal das hastes secundárias e terciárias, evitando o contato dos frutos com o solo o que melhoraria sua qualidade e facilitaria a colheita.

O objetivo desta pesquisa foi comparar a produção de linhagens e híbridos de Maxixe Paulista cultivadas em campo, com práticas de tutoramento em rede agrícola.

\subsection{Material e Métodos}

O experimento foi instalado e conduzido no período de julho a dezembro de 2001, no campo experimental do Departamento de Produção Vegetal da ESALQ/USP, no município de Piracicaba - São Paulo. Segundo a classificação de Köppen, o clima da região é Cwa: subtropical úmido, com três meses mais secos (jun./jul./ago.), chuvas de verão e seca de inverno, temperatura do mês mais quente maior que $22^{\circ} \mathrm{C}$ e média de $21,4^{\circ} \mathrm{C}$.

Linhagens elite de maxixe foram obtidas com ciclos de seleção massal intercalados com ciclos de autofecundação, a partir da população F2 avaliada por Koch \& Costa (1991). Estas linhagens foram avaliadas por Modolo \& Costa (2001a) e denominadas Maxixe Paulista. Suas características são: ausência de espiculosidade, maior tamanho de fruto e formato de folha não-lobulada semelhante ao pepino. Foi feita hibridação entre quatro linhagens elite, num esquema dialélico que resultou em seis combinações híbridas. As linhagens foram designadas como L1, L2, L4 e L60 e suas respectivas combinações H3 (2x1), H5 (4x1), H6 (2x4), H61 (1x60), H62 (2x60) e H64 $(60 \times 4)$.

As mudas foram obtidas em bandejas de poliestireno expandido com 128 células e após 33 dias da semeadura foram transplantadas para linha central de canteiros de 1,20 
$\mathrm{m}$ de largura. O preparo do solo constituiu em subsolagem, uma gradagem e encanteiramento. A condução das plantas foi em rede agrícola com malha de $0,10 \times 0,10$ m. Para sua instalação, foram colocados mourões com altura de 1,5m, amarrados através de catracas com dois arames distanciados de 0,30 a 1,30 do nível do solo, onde foi presa a rede. Adotou-se espaçamento de 1,0 m entre plantas e estas foram conduzidas sem podas e com irrigação por aspersão. Adotou-se a adubação recomendada para a cultura do pepino com base na análise do solo.

A produção foi expressa em número e massa total de frutos/parcela. $O$ comprimento e a largura de frutos, e a espessura de polpa foram determinadas com base na amostragem de 5 frutos/parcela, em duas etapas de colheitas. As medições foram feitas com paquímetro e, no caso da espessura de polpa, considerou-se somente a polpa da parte externa até a placenta, sendo tomado o valor médio entre duas medidas determinadas em seção transversal da parte mediana do fruto. Calculou-se massa média de fruto e relação C/L, obtida pela divisão entre as médias de comprimento $(\mathrm{C})$ e largura (L). Esta relação revela o formato do fruto, sendo que valores próximos a 1 determinam frutos mais arredondados e aqueles mais distantes demostram frutos mais alongados.

A colheita dos frutos iniciou-se 80 dias após a semeadura, sendo realizadas durante quarenta dias num total de 6 etapas. O delineamento experimental foi blocos casualizados, com quatro repetições e parcela de sete plantas. Foi realizada análise de variância e as médias foram comparadas pelo Teste de Tukey a 5\%.

\subsection{Resultados e Discussão}

Segundo Maluf (2001), uma das vantagens da utilização de híbridos de hortaliças em relação a cultivares é o aumento da produtividade precoce devido à heterose. No caso do Maxixe Paulista, não houve precocidade de produção dos híbridos em relação às linhagens (Figuras 6 e 7). A tendência de comportamento das linhagens parentais é semelhante à dos híbridos tanto para número quanto para massa de frutos/parcela nas diferentes etapas de colheita. Ambos, linhagens e híbridos apresentaram dois picos de produção, o primeiro na segunda colheita e o segundo entre a quarta e quinta. 


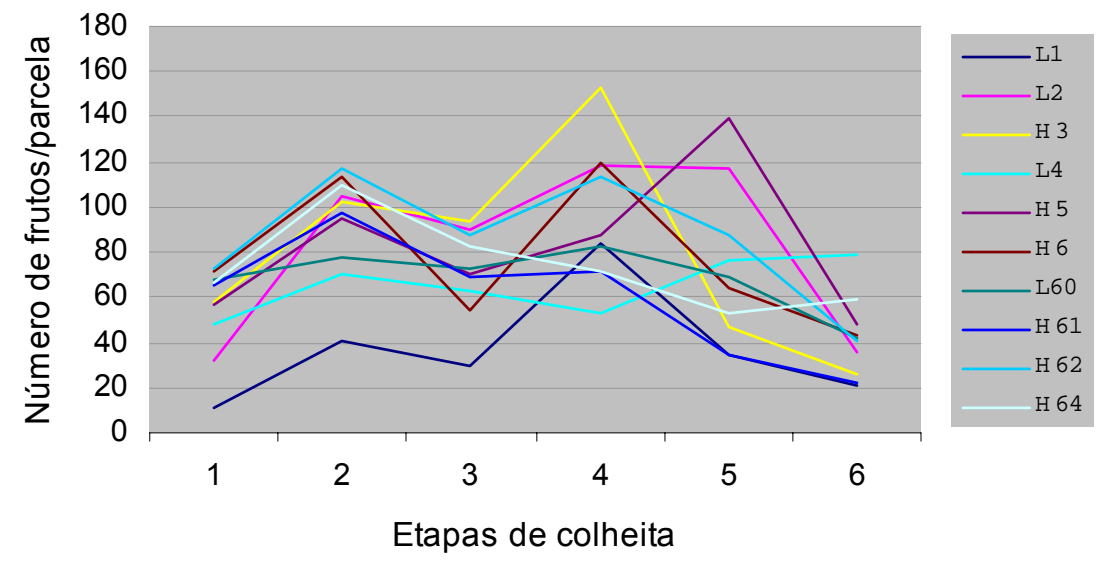

Figura 6 - Número total de frutos/parcela de 7 plantas das linhagens L1, L2, L4 e L60 e híbridos H3, H5, H6, H61, H62, H64 de Maxixe Paulista, durante as 6 etapas de colheita. Piracicaba, ESALQ/USP, 2001.

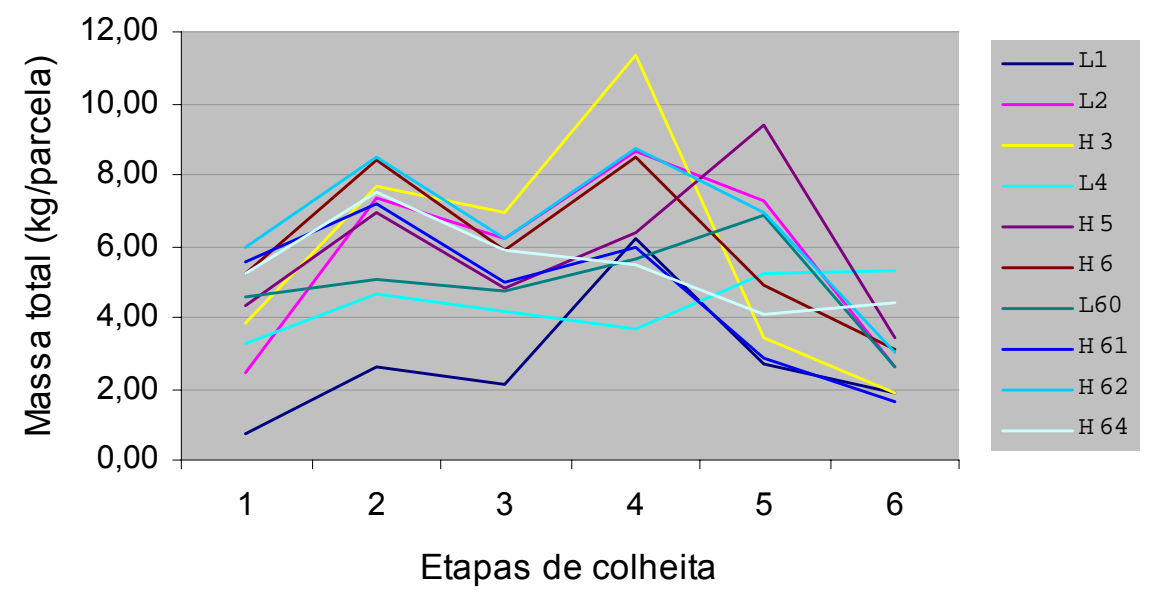

Figura 7 - Massa total (kg) de frutos/parcela de 7 plantas das linhagens L1, L2, L4 e L60 e híbridos H3, H5, H6, H61, H62, H64 de Maxixe Paulista, durante as 6 etapas de colheita. Piracicaba, ESALQ/USP, 2001. 
$\mathrm{Na}$ avaliação quanto aos componentes de produção, híbridos e linhagens apresentaram comportamento semelhante. Quanto à produção total em termos de número de frutos, destacaram-se os híbridos H3, H5 e H62 e a linhagem L2, porém, somente em relação à linhagem L1 (Tabela 10). Para massa total, em quilogramas, novamente houve destaque para os híbridos H3 e H62 em relação à linhagem L1. Com relação ao massa média de fruto, não houve diferença entre híbridos e linhagens.

Tabela 10. Número total (NTF), massa total (MTF) e massa média (MM) de frutos/parcela de 7 plantas, de linhagens L1, L2, L4 e L60 e híbridos H3, H5, H6, H61, H62, H64 de Maxixe Paulista, após 6 colheitas. Piracicaba, ESALQ/USP, 2001.

\begin{tabular}{clll}
\hline Maxixe Paulista & NTF & MTF $(\mathbf{k g})$ & MM $(\mathbf{g})$ \\
\hline L1 & $221 \mathrm{~b}$ & $16,29 \mathrm{~b}$ & $74,59 \mathrm{a}$ \\
L2 & $497 \mathrm{a}$ & $34,40 \mathrm{ab}$ & $69,52 \mathrm{a}$ \\
H3 & $480 \mathrm{a}$ & $37,84 \mathrm{a}$ & $72,63 \mathrm{a}$ \\
L4 & $461 \mathrm{ab}$ & $31,23 \mathrm{ab}$ & $67,79 \mathrm{a}$ \\
H5 & $496 \mathrm{a}$ & $35,28 \mathrm{ab}$ & $71,98 \mathrm{a}$ \\
H6 & $465 \mathrm{ab}$ & $36,05 \mathrm{ab}$ & $77,20 \mathrm{a}$ \\
L60 & $410 \mathrm{ab}$ & $29,34 \mathrm{ab}$ & $71,13 \mathrm{a}$ \\
H61 & $360 \mathrm{ab}$ & $28,18 \mathrm{ab}$ & $77,13 \mathrm{a}$ \\
H62 & $517 \mathrm{a}$ & $39,35 \mathrm{a}$ & $76,27 \mathrm{a}$ \\
H64 & $443 \mathrm{ab}$ & $32,50 \mathrm{ab}$ & $72,70 \mathrm{a}$ \\
C.V. & $23,02 \%$ & $27,71 \%$ & $10,43 \%$ \\
\hline
\end{tabular}

Dentro de cada coluna, médias seguidas pela mesma letra não diferem entre si pelo Teste de Tukey a $5 \%$.

Quanto às características de fruto, não houve diferença entre híbridos e linhagens em massa média, comprimento, largura, relação $\mathrm{C} / \mathrm{L}$ (Tabela 11). A relação $\mathrm{C} / \mathrm{L}$ é uma característica importante para processamento de frutos em conserva, sendo que o valor ideal varia de acordo com o tipo de produto a ser embalado, frutos inteiros ou retalhados. $\mathrm{Na}$ cultura de pepino, o tipo ideal de fruto para processamento em conserva apresenta formato cilíndrico, com relação C/L de cerca de 3,0 (Ribeiro \& Melo, 1989). A relação $\mathrm{C} / \mathrm{L}$ depende da característica do fruto e principalmente do ponto de colheita. No Maxixe Paulista, Modolo \& Costa (2000) atribuíram escala de notas conforme grau de maturidade de semente para definição do ponto de colheita ideal para processamento, 
porém, não foram feitas relações entre este parâmetro e relação $\mathrm{C} / \mathrm{L}$. Os frutos de Maxixe Paulista são mais arredondados que compridos, quando comparados aos do pepino. Portanto, são necessários estudos mais detalhados quanto ao ponto de colheita e relação $\mathrm{C} / \mathrm{L}$ para que sejam definidos valores ideais para processamento.

Para o consumo in natura na forma salada é desejável que o fruto apresente maior espessura de polpa.

Tabela 11. Comprimento (C), largura (L), espessura de polpa (EP) e relação comprimento/largura (C/L) de linhagens L1, L2, L4 e L60 e híbridos H3, H5, H6, H61, H62, H64 de Maxixe Paulista. Piracicaba, ESALQ/USP, 2001.

\begin{tabular}{cllll}
\hline Maxixe Paulista & $\mathbf{C}(\mathbf{c m})$ & $\mathbf{L}(\mathbf{c m})$ & $\mathbf{C} / \mathbf{L}$ & $\mathbf{E P}(\mathbf{c m})$ \\
\hline L1 & $7,25 \mathrm{a}$ & $4,71 \mathrm{a}$ & $1,54 \mathrm{a}$ & $0.57 \mathrm{a}$ \\
L2 & $6,85 \mathrm{a}$ & $4,75 \mathrm{a}$ & $1,44 \mathrm{a}$ & $0.46 \mathrm{ab}$ \\
H3 & $6,19 \mathrm{a}$ & $4,65 \mathrm{a}$ & $1,44 \mathrm{a}$ & $0.53 \mathrm{abc}$ \\
L4 & $7,01 \mathrm{a}$ & $4,82 \mathrm{a}$ & $1,46 \mathrm{a}$ & $0.50 \mathrm{abc}$ \\
H5 & $6,98 \mathrm{a}$ & $4,75 \mathrm{a}$ & $1,47 \mathrm{a}$ & $0.50 \mathrm{abc}$ \\
H6 & $7,26 \mathrm{a}$ & $4,76 \mathrm{a}$ & $1,52 \mathrm{a}$ & $0.50 \mathrm{abc}$ \\
L60 & $6,86 \mathrm{a}$ & $4,69 \mathrm{a}$ & $1,46 \mathrm{a}$ & $0.45 \mathrm{c}$ \\
H61 & $7,24 \mathrm{a}$ & $4,86 \mathrm{a}$ & $1,49 \mathrm{a}$ & $0.53 \mathrm{ab}$ \\
H62 & $7,13 \mathrm{a}$ & $4,83 \mathrm{a}$ & $1,47 \mathrm{a}$ & $0.49 \mathrm{bc}$ \\
H64 & $7,22 \mathrm{a}$ & $4,87 \mathrm{a}$ & $1,48 \mathrm{a}$ & $0.51 \mathrm{abc}$ \\
C.V. & $6,48 \%$ & $3,66 \%$ & $3,94 \%$ & $5.98 \%$ \\
\hline
\end{tabular}

Dentro de cada coluna, médias seguidas pela mesma letra não diferem entre si pelo Teste de Tukey a 5\%.

Os resultados de comparação de híbridos com suas respectivas linhagens não mostram nenhuma superioridade dos híbridos quanto aos seus componentes de produção. Isso pode ser devido à falta de heterose, pois as linhagens são derivadas do mesmo cruzamento e têm similaridade genética. É importante ressaltar que, mesmo sendo simples a técnica de polinização controlada em cucurbitáceas, devido ao tamanho das flores e grande quantidade de sementes em cada cruzamento, a obtenção de híbridos é sempre mais trabalhosa que a manutenção de linhagens (Cardoso, 2001). Nas empresas produtoras de sementes, a produção de híbridos de algumas cucurbitáceas é realizada pela aplicação de reguladores de crescimento. Na cultura do pepino, a aplicação de 
ethephon em plantas monóicas, quando a planta apresenta duas folhas verdadeiras, promove a indução do aparecimento de flores femininas, facilitando a produção de sementes híbridas (Castro, 1998). No maxixe, propõe-se a aplicação deste produto em plantas ainda em estádio cotiledonar ou até o aparecimento da quarta folha definitiva (Abreu, 1988).

$\mathrm{Na}$ cultura do pepino, a prática do tutoramento aumentou de 3 a 5 vezes a produção quando comparada ao cultivo rasteiro (Alvarenga, 1982; Illescas \& Vesperinas, 1989). Para Maxixe Comum, Leal et al. (2000) compararam sistemas de cultivo rasteiro e tutorados verificando que não houve diferenças em termos de produtividade entre eles, porém, a qualidade dos frutos foi superior no cultivo tutorado. No cultivo de Maxixe Paulista em canteiros cobertos com polietileno e fertirrigação, Modolo \& Costa (2001b) encontraram produtividade média entre linhagens elite de 41 $\mathrm{t} / \mathrm{ha}^{-1}$, num período de colheita de dois meses. No presente experimento, considerando-se uma população de 6.500 plantas/ha, estima-se uma produtividade média entre híbridos e linhagens de 36,5 t.ha $^{-1}$, para um período de colheita de quarenta dias.

A rede agrícola se mostrou um ótima opção para o cultivo de Maxixe Paulista na forma tutorada. Devido à forte supressão da dominância apical a planta de maxixe concentra sua frutificação nas ramificações laterais. Como a rede agrícola apresenta fios verticais e horizontais, as hastes secundárias e terciárias da planta foram distribuídas ao longo da rede não deixando os frutos em contato com o solo. Isto possibilitou melhora na qualidade dos frutos e facilidade na colheita, além de dispensar o uso de podas promovendo uma redução do custo de mão-de-obra. É importante ressaltar que, devido ao Maxixe Paulista apresentar frutos lisos, com casca sem espículos, sua fragilidade e sensibilidade a ferimentos é maior, sendo comum a exsudação de goma quando o fruto sofre alguma batida. A condução em rede facilita a visualização dos frutos durante a colheita, diminuindo os riscos de danos e de não-colheita. 


\subsection{Conclusões}

- A produção dos frutos dos híbridos foi equivalente a das linhagens;

- As linhagens são similares aos híbridos quanto ao comprimento e largura de frutos;

- A rede agrícola se mostrou adequada para o cultivo de Maxixe Paulista na forma tutorada. 


\section{CONCLUSÕES GERAIS}

- O cultivo em canteiros com cobertura de polietileno e fertirrigação por gotejamento proporcionou produtividade estimada de $51,89 \mathrm{t}^{-\mathrm{ha}^{-1}}$;

- A planta de maxixe mostrou ser inadequada na condução utilizando o protocolo de tutoramento e podas da cultura do pepino, quando cultivada em ambiente protegido;

- A produção e a qualidade dos frutos dos híbridos de Maxixe Paulista foram equivalentes as das linhagens utilizando a técnica de cultivo em rede agrícola;

- A utilização de rede agrícola para o tutoramento mostrou ser adequada para o cultivo de Maxixe Paulista;

- O Maxixe Paulista apresenta peso médio de fruto superior ao Maxixe Comum no sistema de cultivo em canteiros cobertos com polietileno preto e em ambiente protegido. 


\section{REFERÊNCIAS BIBLIOGRÁFICAS}

ABREU, C.L.M. Efeitos do ethephon (ácido 2-cloro-etil-fosfônico) em maxixe (Cucumis anguria L.). Piracicaba, 1988. 86p. Dissertação (Mestrado) - Escola Superior de Agricultura "Luiz de Queiroz", Universidade de São Paulo.

ALVARENGA, M.A.R.; PEDROSA, J.F.; FERREIRA, F.A. Pepino: cultivares e métodos culturais. Informe Agropecuário, v.8, n.85, p.33-34, 1982.

ANDRIOLLO, J.L. Fisiologia das culturas protegidas. Santa Maria: Ed. da UFSM, 1999. 142p.

ANDRIOLLO, J.L.; DUARTE, T.S.; LUDKE, L.; SKREBSKY, E.C. Caracterização e avaliação de substratos para o cultivo do tomateiro fora do solo. Horticultura Brasileira, v.17, n.3, p.215-219, 1999.

ARAÚJO, J.A.C.; CASTELLANE, P.D.C. Os 10 anos de plasticultura na F.C.A.V. Unesp de Jaboticabal. Jaboticabal: FUNEP, 1996. 104p.

BAIRD, J.R.; THIERET, J.W. The bur gherkin (Cucumis anguria var. anguria, Cucurbitaceae). Economic Botany, v.42, n.3, p.447-451, 1988.

BERJON, M.A.; MURRAY, P.N. Substratos para el cultivo sin suelo y fertirrigacion. In: LORPEZ, C.C. Fertirrigacion: cultivos horticolas y ornamentales. Madrid: Ediciones Mundi-Prensa, 1997. p.287-342.

BRANDÃO FILHO, J.U.T.; CALLEGARI, O. Cultivo de hortaliças de frutos em ambiente protegido. Informe Agropecuário, v.20, n.200/201, p.64-68, 1999. 
BRANDÃO FILHO, J.U.T.; VASCONCELLOS, M.A.S. A cultura do meloeiro. In: GOTO, R.; TIVELLI, S.T. Produção de hortaliças em ambiente protegido: condições subtropicais. São Paulo: Fundação Editora da UNESP, 1998. p.161-194.

CAÑIZARES, K.A.L. A cultura do pepino. In: GOTO, R.; TIVELLI, S.T. Produção de hortaliças em ambiente protegido: condições subtropicais. São Paulo: Fundação Editora da UNESP, 1998. p.195-223.

CARDOSO, A.I.I. Melhoramento de hortaliças. In: NASS, L.L.; VALOIS, A.C.C.; MELO, I.S.; VALADARES-INGLIS, M.C. (Ed.) Recursos genéticos e melhoramento - plantas. Rondonópolis: Fundação MT, 2001. p. 293-325.

CARNEIRO JÚNIOR, A.G.; GUIMARÃES, V.F.; GOTO, R. Substratos favorecem cultura de hortaliças. Agrianual 2002: anuário estatístico da agricultura brasileira. São Paulo, 2002. p.49-50.

CARRIJO, O.A.; MAKISHIMA,N. Princípios de hidroponia. Brasília: EmbrapaHortaliças, 2000. 27p. (Circular Técnica, 22).

CASTELlANE, P.D.; CORTEZ, G.E.P.; ARAÚJO, J.A.C.; BANZATO, D.A. Influência da cobertura do solo na produção de morangueiro (Fragaria ananassa Dutch.), cultivado no sistema de irrigação por microaspersão. Horticultura Brasileira, v.13, n.1, p.74, 1995

CASTRO, P.R.C. Utilização de reguladores vegetais na fruticultura, na olericultura

e em plantas ornamentais. Piracicaba: ESALQ, Divisão de Biblioteca e Documentação, 1998. 92p. (Série Produtor Rural. Ed. Especial)

CORTEZ, G.E.P.; CASTELlANE, P.D.; ARAÚJO, J.A.C.; BANZATO, D.A. Influência da cobertura do solo na produção de morangueiro (Fragaria ananassa Dutch.), cultivado no sistema de irrigação por gotejamento. Horticultura Brasileira, v.13, n.1, p.78, 1995

ESQUINAS-ALCAZAR, J.T.; GULICK, P.J. Genetic resources of cucurbitaceae. Rome: International Board for Plant Genetic Resources, 1983. 101p. 
FARIAS-LARIOS, J.; GUZMAN, S.; MICHEL, A.C. Effect of plastic mulches on the growth and yield of cucumber in a tropical region. Biological Agriculture and Horticulture, v.10, p.303-306, 1994.

FILGUEIRA, F.A.R. Novo manual de olericultura: agrotecnologia moderna na produção na produção e comercialização de hortaliças. Viçosa: UFV, 2000. 402p.

GOTO, R.; DUARTE FILHO, J. Utilização de plástico na cultura do morangueiro. Informe Agropecuário, v.20, n.198, p. 59-64, 1999.

ILLESCAS, E.S.; VESPERINAS, E.S. Tratado de horticultura herbácea. 1. Hortalizas de flor e fruto. Barcelona: Aedos, 1989. 352p.

KOCK, P.S.; COSTA, C.P. Herança de caracteres de planta e fruto em maxixe. Horticultura Brasileira, v.9, n.2, p.73-77, 1991.

LEAL, F.R.; REGO, M.C.A. Influência de diferentes espaçamentos no comportamento do maxixe conduzido em ambiente com meia sombra (compact disk). Horticultura Brasileira, v.19, n.2, 2001 / Apresentado no 40. Congresso Brasileiro de Olericultura, São Pedro, 2000 - Resumo/

LEAL, F.R.; SANTOS, V.B.; SALVIANO, A.A.C. Sistemas de condução e aplicação de cal extinta na cultura do maxixe. Horticultura Brasileira, v. 18, p.542-543, 2000. Suplemento. /Apresentado no 40. Congresso Brasileiro de Olericultura, São Pedro, 2000 - Resumo/

LEPPIK, E.E. Searching gene centers of the genus Cucumis throught host-parasite relationship. Euphytica, v.15, p.323-328, 1966.

LOWER, R.L.; EDWARDS, M.D. Cucumber breeding. In: BASSETT, M.J. (Ed.) Breeding vegetable crops. Wesport: AVI, 1986. p.173-207.

MALUF, W.R. Heterose e emprego de híbridos $F_{1}$ em hortaliças. In: NASS, L.L.; VALOIS, A.C.C.; MELO, I.S.; VALADARES-INGLIS, M.C. (Ed.) Recursos genéticos e melhoramento - plantas. Rondonópolis: Fundação MT, 2001. p. 327355. 
MAROUELLI, W.A.; SOUZA, A.F.; SILVA, W.L.C.; CARRIJO, O.A. Efeito residual de fontes de $\mathrm{N}$ na produção de maxixe em ambiente protegido (compact disk). Horticultura Brasileira, v. 19, n.2, 2001 / Apresentado no 40. Congresso Brasileiro de Olericultura, São Pedro, 2000 - Resumo/

MAROTO, J.V. Horticultura: herbacea especial. Madrid: Grafo, 1994. 611p.

MARTINS, G. Cultivo em ambiente protegido: o desafio da plasticultura. In: FILGUEIRA, F.A.R. Novo manual de olericultura: agrotecnologia moderna na produção e comercialização de hortaliças. Viçosa: UFV, 2000. p.135-153.

MARTINS, M.A.S. Maxixe (Cucumis anguria L.) e seu cultivo em São Luís do Maranhão. São Luís: EMAPA, 1986 (Documento, 8).

MARTINS, S.R. ; PEIL, R.M.; SCHWENGBER, J.E.; ASSIS, F.N.; MENDEZ, M.E.G. Produção de melão em função de diferentes sistemas de condução de plantas em ambiente protegido. Horticultura Brasileira, v.16, n.1, p.24-30, 1998.

MEEUSE, A.D.J. The possible origen of Cucumis anguria L. Blumea, v.4, p.196-205, 1958.

MELO, A.M.T.; TRANI, P.S. Maxixe. In: FAHL, J.I.; CAMARGO, M.B.P.; PIZZINATTO, M.A.; BETTI, J.A.; MELO, A.M.T.; DeMARIA, I.C.; FURLANI, A.M.C. (Ed.). Instruções agrícolas para as principais culturas econômicas. Campinas: Instituto Agronômico, 1998. 393p. (IAC. Boletim Técnico, 200).

MODOLO, V.A.; COSTA, C.P. da. Caracterização e ponto de colheita em maxixe. Horticultura Brasileira, v. 18, p. 476-478, 2000. Suplemento. /Apresentado no 40. Congresso Brasileiro de Olericultura, São Pedro, 2000 - Resumo/

MODOLO, V.A.; COSTA, C.P. da. Condução de maxixe paulista sob ambiente protegido (compact disk). Horticultura Brasileira, v.19, n.2, 2001a./ Apresentado no 40. Congresso Brasileiro de Olericultura, São Pedro, 2000 - Resumo/ 
MODOLO, V.A.; COSTA, C.P. da. Avaliação de linhagens de maxixe paulista (compact disk). Horticultura Brasileira, v.19, n.2, 2001b. / Apresentado no 40. Congresso Brasileiro de Olericultura, São Pedro, 2000 - Resumo/

MODOLO, V.A.; COSTA, C.P. da; TESSARIOLI NETO, J. Caracterização de linhagens melhoradas de maxixe. In: CONGRESSO BRASILEIRO DE OLERICULTURA, 39. Tubarão, 1999. Anais. Tubarão: SBO, 1999. p. 201

OLIVEIRA, C.R. Cultivo em ambiente protegido. Campinas: Coordenadoria de Assistência Técnica Integral, 1997. 31p. (CATI. Boletim Técnico, 232).

PAIVA, M.C. Produção de hortaliças em ambiente protegido. Cuiabá: SEBRAE/MT, 1998. 78p. (Coleção Agroindústria, 18).

PAIVA, W.O. Estimativas de parâmetros genéticos em maxixe (Cucumis anguria L.). Acta Amazônica, v.14, n.1/2, p.39-47, 1984.

PAIVA, W.O. Parâmetros genéticos em maxixe sem espículos. Acta Amazônica, v.24, n.1/2, p.3-8, 1994.

PASSOS, F.A. Influência de sistemas de cultivo na cultura do morango (Fragaria $\mathrm{x}$ ananassa Dush). Piracicaba, 1997. 105p. Tese (Doutorado) - Escola Superior de Agricultura "Luiz de Queiroz", Universidade de São Paulo.

PATERNIANI, M.E.A.G.Z. Hibridação interespecífica no gênero Cucumis L. Piracicaba, 1988. 73p. Dissertação (Mestrado) - Escola Superior de Agricultura "Luiz de Queiroz", Universidade de São Paulo.

PIMENTEL, A.A.M.P. Olericultura no trópico úmido: hortaliças da Amazônia. São Paulo: Agronômica Ceres, 1985. 332p.

QUEIROZ, M.A. Potencial do germoplasma de cucurbitáceas no nordeste brasileiro. Horticultura Brasileira, v.11, n.1, p.7-9, 1993.

RAMALHO, M.A.P. Hábito de florescimento e frutificação do pepino (Cucumis sativus L.). Piracicaba, 1973. 48p. Dissertação (Mestrado) - Escola Superior de Agricultura “Luiz de Queiroz", Universidade de São Paulo. 
RESENDE, G.M. Rendimento de cultivares de maxixe em função de épocas de cultivo. Horticultura Brasileira, v.16, n.2, p.167-171, 1998.

RIBEIRO, A.; MELO, P.C.T. A moderna tecnologia na cultura do pepino. Paulínia: Estação Experimental de Pesquisas de Hortaliças, 1989. 26p.

ROBINSON, R.W.; DECKER-WALTERS, D.S. Cucurbits. New York: CAB International, 1997. 225p.

SALISBURY, F.B.; ROSS, C.W. Plant physiology, 3.ed., Belmont:Wadsworth, 1985. $678 \mathrm{p}$.

SIMMONDS, N.W. Principles of crop improvement. New York: Longman Group, 1979. 408p.

SONNENBERG, P.E. Olericultura especial. 3.ed. Goiânia: Universidade Federal de Goiás, 1985. 143p.

TESSARIOLI NETO, J.; MINAMI, K.; JÚNIOR, M.J.P.; PASSOS, F.A. Efeito da cobertura permeável e impermeável sobre o solo e a planta de morangueiro na temperatura do solo. Horticultura Brasileira, v.12, n.1, p.105, 1994a.

TESSARIOLI NETO, J.; MINAMI, K.; SANTOS, R.R.; PASSOS, F.A. Efeito da cobertura permeável e impermeável sobre o solo e a planta na produção de morangueiro. Horticultura Brasileira, v.12, n.1, p.106, 1994 b.

TESSARIOLI NETO, J.; MINAMI, K.; SCARPARE FILHO, J.A.; PASSOS, F.A. Efeito da cobertura permeável e impermeável sobre o solo e a planta no desenvolvimento vegetativo do morangueiro. Horticultura Brasileira, v.12, n.1, p.106, 1994c.

TRANI, P.E.; GROPPO, G.A.; SILVA, M.C.P.; MINAMI, K.; BURKE, T.J. Diagnóstico sobre a produção de hortaliças no estado de São Paulo. Horticultura Brasileira, v.15, n.1, p.19-24, 1997. 
YOKOYAMA, S. Genética e produção de sementes de maxixe (Cucumis anguria L.) Piracicaba, 1987. 115p. Dissertação (Mestrado) - Escola Superior de Agricultura "Luiz de Queiroz", Universidade de São Paulo.

YOKOYAMA, S.; SILVA JÚNIOR, A.A. Maxixe: uma hortaliça pouco conhecida. Agropecuária Catarinense, v.1, n.3, p.12-13, 1988 